\title{
CHIMËRES
}

A Journal of French and Francophone Literatures and Cultures

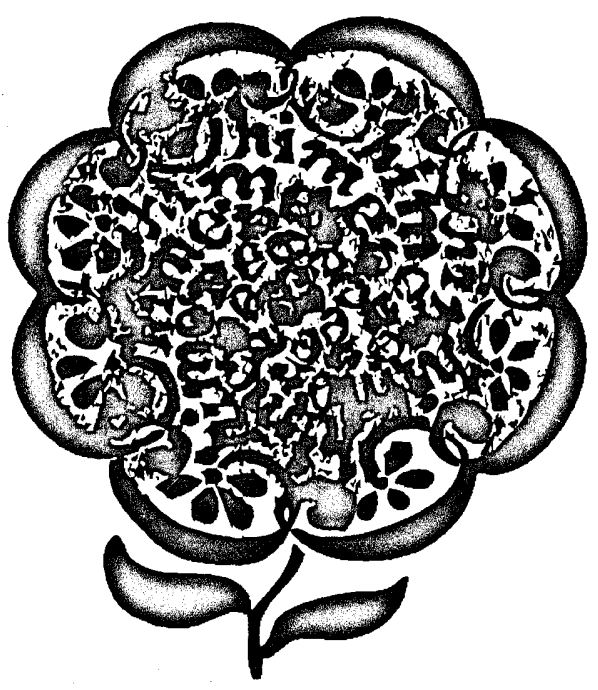

The University of Kansas Volume XXXI Spring 2010 
Editor: Jeff Kendrick

Co-Editor: Gilles Viennot

Faculty Sponsor: Professor Caroline Jewers

Editorial Staff:

Gillian Weatherley, Treasurer

Evan Foster, Secretary

Mrinmoyee Bhattacharya

Brian Moots

Ashley Peterson

Website: http://www.ku.edu/ chimeres

Chimères

The University of Kansas

Department of French \& Italian

2103 Wescoe Hall

Lawrence, KS 66045

Tel. (785) 864-4056

email: chimeres@ku.edu

We extend our appreciation to the Faculty and Staff in the Department of French \& Italian, the Graduate Student Organization Fund, and Ms. Pam LeRow from the College of Liberal Arts and Sciences Digital Media Services at the University of Kansas for their generous assistance and support of this journal. 
Letter from the editor

Jeff KENDRICK

This Issue's Contributors

Carte blanche

Richard GOLSAN. IX

The Francophone Writer at the Crossroads of Languages

Peter W. VAKUNTA.

The Weight of Secrets: Hidden Mirrors of Identity in Aki Shimazaki's Pentalogy

Peter SCHULMAN.

The Shaping of the Nation in Nanon and 93

Alice AUDOIN

Understanding Marcel Proust's Law of Desire Brody SMITH.

Patterns of Feminine Discourse in Samuel Beckett's Pas Moi

De. Marzia CAPORALE. 

This issue of Chimeres is in many ways coupled with its chain of predecessors. Intermittently for over forty years, the graduate stu1 dents at the University of Kansas have worked together to produce a quality literary journal that publishes engaging articles. This year is no exception. We delighted in a record number of submissions and enjoyed reading every one of them. I have come to believe that one of the greatest skills a young editor learns is discerning between good and best, and sometimes the distinction is extremely difficult to make. The editorial staff add invaluable insights, and their recommendations are in large part reflected in the final selections that you will enjoy in the following pages. Like so many of those who have blazed the publishing trail before us, we are astonished at the idea that a complete journal is finally coming together and that we are still alive to see it happen.

As in past issues, we are delighted to welcome a guest scholar into our discussion. Professor Richard Golsan graciously agreed to include an essay with this issue, and it dovetails nicely with the recurring theme of identity that runs through the other articles. Professor Golsan also met with the editorial staff last year, and his advice and comments are still appreciated. Special thanks, also, to Professor Van Kelly for inviting Professor Golsan and arranging our roundtable. I would be remiss if I did not extend our appreciation to the faculty of the Department of French \& Italian and, especially, Professors Tom Booker, Van Kelly, Allan Pasco, and Paul Scott who shared their expertise and gave their time to help with the journal. Of course, as always, where would we be without the constructive and practical advice of our advisor, Professor Caroline Jewers? A sincere, heart-felt thanks to her seems almost inadequate.

And so, the Chimères chain receives another link. As young scholars ourselves, we have come to appreciate better the world of academic publishing ... its joys and pitfalls. We have learned to look forward to opening that envelope or e-mail from the editor's desk. The helpful comments and suggestions for improvement after a careful reading are worth the wait. We trust that you, our readers, will also relish in the fruits of our contributors' labors. 



\section{This issue's contributors}

Alice Audoin is a graduate student at the Johns Hopkins University. She is currently writing her dissertation on French travelers to the United States in the twentieth-century.

Dr. Marzia Caporale is Assistant Professor of French and Italian and Associate Faculty in Women's Studies at the University of Scranton. Her current research interests include French and Francophone Women Literature and Cinema. She is the author of "The Cinematic Gaze as Social Activism: Yamina Benguigui from Documentary to Fiction" to appear in the next issue of Al-Raida, the Quarterly Journal of the Institute for women's studies in the Arab world.

Peter Schulman is Associate Professor of French and International Studies at Old Dominion University. He is the author of The Sunday of Fiction: The Modern French Eccentric (West Lafayette, In: Purdue University Press, 2003) and, Le Dernier Livre du Siècle (Paris: Romillat, 2001). He has co-edited three volumes: Chasing Esther: Jewish Expressions of Cultural Difference (Haifa/Santa Monica: Kol Katan Press, 2006); Rhine Crossings: France and Germany in Love and War (Albany:SUNY Press, 2005); The Marketing of Eros: Performance, Sexuality and Consumer Culture (Essen: Die Blaue Eule, 2003). He has also translated Jacques Réda's Suburban Beauty (Halifax: VVV Editions, 2009); Celine Zins' Adamah (Arlington: Gival Press, 2008) and Jules Verne's The Secret of Wilhelm Storitz (Lincoln: University of Nebraska Press, forthcoming). He is also a translator for Ellery Queen's Mystery Magazine.

Brody Smith is a graduate of the University of Texas and the University of California, and he is currently completing his doctoral dissertation at the University of California, Davis. His project examines the phenomenon of transcendent desire in Rutebeuf's poem La vie de sainte Marie l'Egyptienne. His research interests include critical theory, hagiography and Marcel Proust.

Peter Wuteh Vakunta teaches French language, literature and culture at the University of Wisconsin-Madison where he obtained his $\mathrm{PhD}$. He is poet, essayist, story-teller and novelist. His award-winning novel, No Love Lost, was published in 2009. Vakunta's literary works have won awards in the US, UK and Africa. He is currently writing a book titled Emerging Perspectives on the Francophone Novels of Africa, Canada and the Caribbean. 



\section{European Identity and American Hegemony: Recent Perspectives of Pascal Bruckner and Tzvetan Todorov}

$\mathrm{I}$

$\mathrm{t}$ is probably a surprise to no one on either side of the Atlantic that since the attacks of September 11,2001, the invasion and occupation tions with much of Western Europe, and especially with France, have been seriously strained or, to use the phrase of the sociologist Michel Wieviorka, been placed sous pression. In France in the immediate aftermath of 911, expressions of sympathy and solidarity were initially forthcoming in many quarters. These expressions were perhaps best exemplified and indeed summed up in the title of Jean-Marie Colombani's 12 September editorial in Le Monde, "Nous sommes tous des américains," - "We are all Americans." At the same time, however, there were also those who expressed satisfaction in witnessing a disaster that, they believed, many if not most citizens of the world secretly or not-so-secretly desired. The most notable of these was Jean Baudrillard whose jubilation, expressed in an editorial in Liberation, bordered for many on the obscene (Baudrillard).

With the build-up to and invasion of Iraq, what support and sympathy there was for America in Europe and, conversely, whatever solidarity at least the Bush administration and its supporters felt for "Old Europe" rapidly eroded. Jacques Chirac and Dominique de Villepin, with the backing of Gerhard Schroeder, opposed the war in the UN and elsewhere, and Robert Gates, current Secretary of Defense and former president of Texas A\&M University, announced in a lecture at the Bush School at Texas A\&M that the fabric of Franco-American friendship had been permanently and irreparably torn. As the horrors of Abu Graib and then Guantanamo came to light, erstwhile French supporters of the invasion of Iraq, including most notably Pascal Bruckner, publicly denounced American excesses which, they believed, violated the very democratic and humanitarian principles that justified the invasion in the first place. Other intellectuals, with Em- 
manuel Todd and Ignazio Ramonet of Le Monde diplomatique in the lead, voiced cries of alarm at what they viewed as a newly-emergent American Empire taking shape around the globe. More reasonable voices like those of Tzvetan Todorov and Henry Rousso expressed grave concerns that too many in the West, and especially in Bush's America, were buying into Samuel Huntington's dubious notion of a "Clash of Civilizations" that necessarily entailed a war with Islam. Only André Glucksmann, who viewed the War on Terror and the struggle in Iraq as a Manichean and cosmic struggle between Good and Evil, continued to support America unconditionally. In his 2003 essay Ouest contre Ouest, Glucksmann went so far as to characterize Bush as a kind of metaphysical cowboy, a Gary Cooper in High Noon who, like a Shakespearean or Greek tragic figure, must go it heroically alone in fighting and vanquishing the villains.

Happily, things are changing, and despite the economic "crash" European attitudes toward and understanding of America are to all appearances undergoing a generally positive transformation with the election of Barack Obama. But this does not mean that the troubling rifts and events of the recent past have been forgotten. In fact, quite the reverse. In the works of most intellectuals in Europe and especially France, these differences continue to have a profound impact in shaping both conceptions of European identity and American hegemony. These conceptions vary, of course, from one intellectual to the next, and, where European identity is concerned, they are also deeply affected by other considerations - immigration, Europe's recent past and especially the terrible legacies of Nazism and Communism, and so on. But, as I hope to show here, the global events since 911 do provide the frame, or at least a broad backdrop for many, if not most recent, meditations on European identity and American hegemony.

By way of examples - and as the subtitle of my essay suggests - I would like to discuss recent writings dealing with European identity and American hegemony by two of France's and Europe's leading public intellectuals, Pascal Bruckner and Tzvetan Todorov. In works like Bruckner's 2006 essay La Tyrannie de la pénitence and Todorov's 2003 essay Le nouveau désordre mondial and his more recent work, La peur des barbares. Au-delà du choc des civilizations, published in September 2008, the two philosophes focus primarily on these issues - and their inevitable interconnectness - while at the same time delineating and identifying a cluster of themes around which these conceptions are articulated. In the case of Europe, these include national and cultural identity and ethnocentrism, as well as the tragic legacies of Europe's recent past mentioned 
above. Where American hegemony is concerned, they include Empire of course, and the so-called "Clash of Civilizations." But they also include the principles and definition of democracy itself.

Although Bruckner and Todorov have shared the Parisian, and frequently the European and global spotlight for years, much separates them in background and outlook, and this certainly influences their respective conceptions of European identity and American hegemony. As one example of where these divergences have manifested themselves, consider May 1968, which the two men experienced from very different places, generational as well as geographical and intellectual. Todorov, some ten years Bruckner's senior, was teaching in the US during the student revolts and strikes. And, as he writes in the 2002 autobiographical work Devoirs et délices, at the time, largely as a result of having spent his adolescence in Communist Bulgaria, he was suspicious of political activism of any sort, other than in the defense of the individual and his or her dignity. As he phrases it, "The global effect of living under Communism, at bottom," was not to make a "virulent anti-Communist" of him, but rather to make him "virulently anti-political" (Devoirs 47). When he arrived in France, moreover, the stylish activism of the young western Europeans around him struck Todorov as artificial and insincere. Finally, the experience of Communism taught him to be suspicious of any collective actions undertaken in the name of "Humanity," as these actions most frequently prove more destructive than constructive. In fact, they often accomplish quite the opposite of what was intended.

By contrast, while not an activist in May 1968 - in fact he considered himself to be primarily an onlooker - Bruckner, a native French person and Parisian, was politically energized by the event. He adopted what he describes as a "libertarian extreme left position" during the student revolts. For him, May 68 produced an enormous "anthropological transformation" in France and Europe, whose repercussions are still not fully grasped today. It also generated as well a "great tide of liberty," with positive as well as very negative results, especially for the societies and cultures of Western Europe. To a significant extent, Bruckner's novels have focused on what he would considers to be the positive aspects of the legacy of May 1968, that is, women's liberation and especially the sexual revolution, whereas his essays focus on some of the negative legacies, for example, revolutionary tiermondisme, to be discussed shortly (Interview, 12-4).

Finally, by way of understanding the divergent takes of Bruckner and Todorov on European identity and American hegemony, it is important to consider divergences in their views on the intellectual's role in contem- 
porary society. These views may, in fact, seem somewhat contradictory, given the two men's respective attitudes toward May 68.

Todorov's aim as an intellectual is, as he has written in a recent preface to Raymond Aron's Mémoires and in essays on the Resistance hero Germaine Tillion - both figures he greatly admires - is to fulfill the role of what he labels the "Responsible Intellectual." The "Responsible intellectual" does not embrace partisan causes, or national, or European, or ideological interests, but remains committed to a higher cause - and perhaps the highest cause - which is serving truth and justice. Along these lines, Todorov is fond of quoting Germaine Tillion's statement: "I believe with all my heart that justice and truth count more than any political cause" (avant-propos 9).

By contrast - as André Glucksmann has written recently — Bruckner is less a committed or "responsible" intellectual in his primary orientation than he is a moraliste (26). While Bruckner does not eschew political involvements - he was very active in denouncing Serb aggression in the 1990s, and earlier, American and Chinese complicity with the Pol Pot regime in Cambodia, the primary aim of his essays is to dissect the ills of contemporary Europe and, more broadly, to expose the hypocrisies and failings of Western democratic societies. As Todorov himself acknowledges, at this Bruckner is a master.

Let me turn directly now to the two writers' conceptions of European Identity and American Hegemony. I will begin with Pascal Bruckner. In a perceptive recent essay written about Bruckner's work by Paul Berman, Berman argues that the central and unifying theme of all of Bruckner's major essays is European self-hatred (47-9). For Bruckner, this self-hatred is not an intermittent or superficial sentiment experienced only in relation to specific events or circumstances, it is a complex, profound and often paradoxical and "subterranean" cultural and psychological current that has characterized European modernity over the last century, and especially since World War II. It manifests itself in a variety of ways and circumstances, and often hides its true motivations and outlooks. When examined closely, it is based in its essence on arrogance parading itself as modesty and generosity, ethnocentrism disguised as cultural openness, and political and cultural resentment presenting themselves as reasoned critique.

Bruckner's first book-length foray into European self-hatred appeared in 1983, in an essay denouncing revolutionary tiermondisme, or "ThirdWorldism" entitled Le Sanglot de l'homme blanc. In that work Bruckner's 
ire was directed in the first instance at left-wing intellectuals, most notably Jean-Paul Sartre who, in Bruckner's view, blindly and uncritically celebrated liberation movements and governments in formerly colonized countries in Africa, Latin America, and Asia. According to Bruckner, tiermondistes like Sartre and Frantz Fanon, author of The Wretched of the Earth, either ignored or, conversely, deliberately celebrated the violence and inhumanity of many of these movements and regimes on the grounds that these excesses was liberating, purifying, and justified. The fact that this violence and inhumanity went precisely against principles upon which anti-colonialism was supposedly based - equality, human dignity, and self-determination - mattered little or not at all.

The reality that tiermondisme was misguided and hypocritical, and indeed often criminally so in both cases was, however, only part of the problem. Tiermondisme in Bruckner's view was also at heart a hidden expression of disdain and indifference directed precisely toward the formerly colonized peoples it claimed to support. This disdain and indifference, moreover, expressed itself in a false and condescending sympathy for masses and peoples that in fact ignored the harsh realities of the daily lives of individual human beings. Rather than fostering a true openness toward the formerly-colonized Other, tiermondisme sealed off any real contact by substituting a false and distancing sympathy for genuine empathy and understanding.

But if tiermondisme paradoxically revealed a secret and distancing disdain toward the Other, it also ultimately exposed a profound selfloathing on the part of the tiermondiste and indeed the European himself. For Bruckner, to idolize or idealize North African or Latin American indigenous peoples, and to seek out and partake superficially in their cultures is in the final analysis to seek to escape from one's own being and identity as well as one's own culture. Moreover — and here Bruckner's aim was explicitly political - the uncritical adulation of the Third World and especially its revolutionary politics of the 1970s and early 1980s also allowed the tiermondiste to express his solidarity with the formerly colonized in their hatred of the great enemy of the Third World: America.

Before leaving the discussion of Le sanglot de l'homme blanc it is important to stress a few points made in the book that still characterize Bruckner's attitudes today. First, the self-hatred as well as the secret ethnocentrism - or solipsism - of the tier-mondiste does not belong exclusively to him or of his successors, but in fact to all modern and contemporary Europeans. Textually, this is evident in Bruckner's deliberate 
slippage from a distancing third-person to an uncomfortable first-person "nous" in his analyses and accusations. Second, European attitudes, even towards their own formerly colonized peoples, are influenced by and ultimately inseparable from their animosity toward America. This animosity, moreover, hides a secret envy. America is more powerful, and it is not haunted by self-doubt or hypocrisy in the same way that Europe is. Bruckner's view of America in Le Sanglot may be overly rosy - and he will revise this view in very recent writings, as we shall see - but it is clear that for him, already in 1983, European identity and American hegemony are intimately connected and in fact inextricably intertwined.

In many ways, Bruckner's 2006 essay, La tyrannie de la pénitence, written more than twenty years after Le Sanglot de l'homme blanc picks up precisely where the latter work left off, in that its central focus remains European self-hatred. Except that in La tyrannie de la pénitence, the most recent manifestation or symptom of European self-hatred that Bruckner identifies and dissects is not tiermondisme or its recent avatars, but Europe's unhealthy obsession with the horrors of its recent past. Second, while Europe's self- conception is infected by its secret envy of America, America itself is by no means above reproach, and Bruckner delivers a blistering indictment of the US in these pages. This indictment, coupled with Bruckner's continuing focus on European self-hatred, sets the stage for the writer's somewhat surprising conclusion in this work, and also in subsequent essays, and that is the need for and in fact necessity of a European-American reconciliation and collaboration in order to forward democracy worldwide.

In denouncing contemporary Europe's - and France's - obsession with the horrors of its recent past in La tyrannie de la pénitence, Bruckner is by no means attempting to downplay the horrific crimes of Nazism and Vichy, or of Western Europe in its former colonies, or of Communism in Eastern Europe and worldwide. What he is attacking is a fixation on fulfilling a so-called "duty to memory" that is reminiscent of tiermondisme in the hypocrisies and bad faith that it disguises or attempts to hide. First, like tiermondisme, the "duty to memory" betrays a secret self-satisfaction and even arrogance: Europeans can claim to have experienced the worst of the worst of History, and they therefore consider themselves in a position to give definitive lessons about History with a capital " $\mathrm{H}$ " to others. The process allows them, moreover, to diminish the horrors others have experienced and at the same time ignore contemporary crimes, traumas, and genocides elsewhere in the world. These include not only the wars and genocides in the former Yugoslavia - where America, and not Europe, 
led the charge to intervene - but also in Rwanda, Chechnya, Darfur, and other trouble spots.

The duty to memory also allows Europeans to revise History for their own liking by putting it at the service of the politics of memory. Thus the crimes of colonialism become comparable to the worst horrors perpetrated by the Nazis - Israelis become Nazis in their suppression of Palestinians, and so-on.

Finally, in obsessively fulfilling their "duty to memory," in becoming in recent years what Bruckner derisively refers to as "athlètes de la pénitence," Europeans ignore the obligation to act in the present, while focusing exclusively on the past. For all intents and purposes they are attempting to escape from History at precisely the point where History cannot be ignored. For Bruckner, the "History" of the present is essentially the wars in Iraq and Afganistan, the dangers of Islamic fundamentalism, Abu Graib, Guantanamo - in short, the world since 911. And this brings us to America.

If, in La Tyrannie de la pénitence Europe is, as Bruckner describes it elsewhere a "regret," a refugee from History, America, and certainly post-911 America is very much the opposite. Living fully in the present and characterized by a reckless dynamism, America continues to inspire envy, along with a deep animosity, among Europeans now paralyzed by their past. But if America can be lauded for its energy, its will to look toward the future, it is also subject to Bruckner's withering criticisms on many crucial points. In a section of La tyrannie entitled "The Blustering Colossus" Bruckner chastises America, first, as a country obsessed with its sense of "election" and its own superiority. It is this sense of superiority, moreover, that allows Americans to believe that they can "se soustraire aux devoirs qui incombent à l'humanité ordinaire" (Tyrannie 234). Americans can - and they do - ignore what Bruckner describes as les lois communes, which would dictate to all on the planet the necessity to, for example, work in concert and in good faith with the UN and the International Court of Justice in the Hague. In enthusiastically endorsing the war in Iraq and at least tacitly accepting and thus condoning the horrors of Abu Grahib and Guantanamo and the continued use of torture by the American military and intelligence, they allow the very principles on which American democracy has been built to be tarnished and undermined. Moreover, the same is true when they allow themselves to be spied on by their own government. And if this were not enough, in their large majority they cheered on the Bush administration's "crazy dream, in the Second Gulf War, to reshape the face of the Middle East" (La Tyrannie 235). 
If la tyrannie de la pénitence paints a very bleak picture of European passivity and navel contemplation and American arrogance and recklessness, what if anything can be done to cure the ills besetting Europe and European self-understanding on the one hand, and the excesses of American sovereignty, of American Empire, on the other? Bruckner's answer is to propose a new Trans-Atlantic Alliance of sorts, but with somewhat different aims and with a greater wisdom and self-understanding than manifested in previous efforts along these lines. First, Bruckner argues that the spread of democracy and the struggle against fanaticism, religious and otherwise, is not a choice but a necessity and a duty that America and Europe must undertake together. But they must recognize at the outset that, in Bruckner's words, democracy is a "process" and not something to be imposed at the point of the gun. Second, Europe and America must learn from each other in order to cure each other's ills. America's tendency toward a reckless military and political adventurism, certainly in the Bush years, can and must be tempered by a European caution learned from the terrible consequences of its own tendencies along these lines in the $20^{\text {th }}$ Century. Europe, on the other hand, can learn to get over its paralyzing "duty to memory" and therefore its own pessimism and solipsism be embracing - within reason - America's optimism and forward-looking can-do spirit. Finally, as Bruckner has argued most pointedly in a recent lecture entitled "The Provincialization of the West," America, weakened especially by the endless war in Iraq, must learn to accept a more "modest" assessment of its own strength, a lesson well-learned by a chastened Europe. Conversely, Europe must overcome its own tendency to underestimate its own strength and accept a leadership role on the world-stage. This is a lesson it can learn from America.

In turning from Pascal Bruckner's perhaps surprisingly optimistic and grand vision of a Euro-American alliance for self-improvement and the spread of democracy to Tzvetan Todorov's very different notions of Europe and America and the implications of what Todorov labels le nouveau désordre mondial, it is important at the outset to underscore two similarities in outlook that shape both men's perceptions, especially of Europe's past and European identity.

First, like Bruckner, Todorov has been sceptical of tiermondisme and the European intellectual left's embrace of it. In The Morals of History, Todorov denounces the dangers of what he calls "post-colonial nationalism" and its European champions, Sartre for instance. In its more extreme forms "post-colonial nationalism" does not embrace in Todorov's view a 
truly liberational politics. Rather in its calls for a purifying revolutionary violence, it espouses the "darker side" of the European tradition in the figures of Nietsche, Barrès, and Sorel. In this, ironically, colonialism and its ideology win an ironic and "dark victory" over those that seek to defeat them (Morals 58-9).

Also like Bruckner, Todorov is extremely skeptical of Europe's ongoing and troubling obsession with its past. In the 1995 essay Les Abus de la mémoire, Todorov insists that the so-called "duty to memory" does not and cannot eradicate the horrors of the past. In fact, it only distorts the past and turns those who emphasize it into perpetual backward-looking victims who ignore the crimes of the present in the process. For Todorov, the solution to the problem is to make memory not "literal" - that is, narrowly focused on one's own victimage, but "exemplary" where the memory of past injustices becomes a kind of categorical imperative to prevent comparable crimes in the present and future.

If Bruckner and Todorov agree, more or less, on these aspects of Europe and especially its recent past, they strongly diverge on a number of more recent issues affecting European identity today, Europe's role in facing internal and global crises, and, finally, the role of America in the world of the present. Let me begin with the second and third of these concerns, and address two recent moments of crises in particular where the differences in outlook between Bruckner and Todorov are readily apparent: the break-up of the former Yugoslavia in the 1990s and the American-lead invasion of Iraq.

Despite the fact that, as already noted, Bruckner is primarily a moraliste and an ambivalent intellectuel engagé, he has been prominently involved and very outspoken in two recent instances. First, he argued vehemently in favor of intervention in the Balkans to stop Serb aggression and genocide in Bosnia, and then, in the late 1990s, he took the same position on Kosovo. Second, he was a strong early supporter of the invasion of Iraq, co-signing a petition with André Glucksmann, Bernard Kouchner, and Romain Goupil which appeared in Le monde on 3 March 2003 entitled "Saddam doit partir de gré ou de force." Although, as noted as well, Bruckner has since renounced his support of the invasion and denounced Bush and American adventurism, his support of the war, based on the droit d'ingérence or "right to intervene" when national leaders are oppressing and brutalizing their own people, has earned him the label of a French "neo-conservative" in some quarters. Moreover, as the discussions here have shown, Bruckner's recent critique of American adventurism by no means implies that America should withdraw from the world stage and adopt an isolationist stance. 
In order to understand Todorov's views both on the war in the Balkans and the invasion of Iraq, it is important to return to two points made already concerning Todorov's background and his views on contemporary Europe. The first point is that, as a native Bulgarian who experienced Communist totalitarianism directly, Todorov's view is obviously not entirely that of a "Western European" as is Bruckner's. Rather, his perspective, as he colorfully describes it in the title of a the recent book, is that of an homme dépaysé, divided between Eastern and Western Europe. And because of his background in a totalitarian state, he is more skeptical of massive "collective actions" in the name of higher ideals like "democracy" or "humanitarian intervention."In his reservations concerning America's current role on the global stage, moreover, there are also, perhaps, echoes if not memories of a Cold War mind set.

The second point is that, very much in keeping with his take on Europe's obsession with its recent past, the political actions of the West today, as he writes in Le nouveau désordre mondial, are dangerously skewed by the memory of Nazism. That memory, according to Todorov, allows for only two courses of action: a Munich-like passivity and a Dresden-like destructiveness, where technological superiority results in the devastation of a defenseless and mostly civilian enemy. In the 2000 essay Mémoire du mal, Tentation du bien, Todorov denounces NATO and the West's following of the latter course of action in Kosovo in dropping so-called "humanitarian bombs" on Serbian civilian populations ostensibly in defense of a victimized Albanian Kosovar population.

Todorov's criticisms of NATO's bombing of Kosovo and the American-led invasion of Iraq - which he denounces on several scores in Le nouveau désordre mondial, including the terrible injustice of killing thousands of civilians in supposedly fighting a "war on terror" and the hypocrisy of spreading democracy through naked aggression - have earned Todorov the label of Anti-American in some quarters. He has rejected this label in arguing in a recent interview that his criticisms of the Iraq and of Bush administration policies there are views shared by more than half the American population. Moreover, his criticism of American actions are motivated by a deep affection for this country which he feels, has been damaged economically, morally, and diplomatically by the entire tragic misadventure.

So, finally, if in their most recent writings Todorov and Bruckner share a rejection of recent American militarily adventurism and arrogance, how are their respective views different where American hegemony is concerned? Moreover, how do their respective views on the topic affect 
their views of Europe in relation to America? Finally, how is European identity itself conceived? On the first score, it is perhaps fair to say that Todorov remains more deeply skeptical than Bruckner of American hegemony and America's role in the world. After all, Todorov's most recent book, La peur des barbares focuses on and denounces the so-called clash of civilizations, defined by an American intellectual and pursued, in effect, in recent American foreign policy. It also underscores the cost in moral and human terms of carrying out practices such as torture that dehumanize the torturer as much as the tortured, and are inimical to democracy itself.

It is also safe to say that, as opposed to Pascal Bruckner, Tzvetan Todorov does not envisage or call for a new trans-Atlantic alliance on the order described by Bruckner, although for him America remains a partenaire privilégié. Moreover, the aim of spreading democracy globally is a more dangerous and ultimately more dubious process for Todorov than it is for Bruckner. Todorov also argues in Le nouveau désordre mondial Europe needs to be to be more militarily self-sufficient, not only in policing itself and protecting its borders, but in projecting its power to global crises and hot spots. While Bruckner also believes Europe needs to strengthen itself militarily, it seems clear that for him European intervention abroad needs to be undertaken more in concert with America, which itself needs to respect, like other nations, the authority of the United Nations.

Finally, what of European identity itself? Simply by virtue of his background Pascal Bruckner is seemingly more directly "rooted" in a Western European and specifically French context. Some of his recent work points in fact in that direction in that, in essays like "The Crises of Patriotism" Bruckner addresses and at least implicitly praises the sacrifices made for the survival of European nations and national cultures and expresses a genuine concern for the loss of national sentiment in Europe today. Moreover, despite his moraliste's condemnations of the modern European in works like Le sanglot de l'homme blanc and La tyrannie de la pénitence, in these works neither Bruckner's calls for a true openness toward the Other nor his demand for a healing forgetfulness of the crimes of the past require a renunciation of one's European identity or Europe's rich heritage. Quite the reverse. In fact, in a brief essay on the idea of cosmopolitanism published in 2000 entitled Le Vertige de Babel Bruckner calls both for a deep and authentic appreciation of the language and culture of the Other and a pride in and understanding of one's own roots and heritage. For Bruckner, the former is not possible without the latter.

In a very recent essay entitled, appropriately, "European Identity," Tzvetan Todorov argues for what he describes a "Plurality as the Basis 
of Unity" in the European context. Todorov's "Plurality" resembles Bruckner's cosmopolitanism in that both advocate a conception of European identity that embraces other national cultures besides one's own. But Todorov's "plurality" is more explicitly expansive in that for him European identity could not have been forged without the contributions of non-European cultures, and Todorov mentions Muslim cultures as well as Chinese and Indian culture. Moreover, Todorov is less sanguine in embracing the benefits of Europe's own cultural heritage, since this is at best a mixed blessing. As he states, "The idea of equality among all human beings comes from Europe's history, but that of slavery is by no means foreign" ("European Identity" 6).

The last section of Todorov's essay on European Identity is entitled "Europe and the Western World" and this brings us full circle, in that for Todorov as for Bruckner, European Identity is ultimately inconceivable today in isolation form the United States. Moreover, Europe's tendency toward what Todorov labels angélisme, or taking an "angelic posture" towards one's enemies must be tempered by American realism if the European ideal of true plurality is to be realized.

But - and to conclude here - for Todorov as for Bruckner, it is also incumbent on Americans to learn from Europe's more peaceful approach in renouncing what he describes as our "hegemonic temptation" and our will to "demonize" our enemies. If both these objectives are realized, if America and Europe can truly learn from each other, then, as Todorov writes, this will be a "true contribution to the consolidation of peace on earth" ("European Identity" 15). Bruckner could not agree more.

\section{Note}

1. The lecture was delivered at Texas A\&M University on 19 October 2008 .

\section{Works Cited}

Baudrillard, Jean "L'Esprit du terrorisme." Le monde, 2 November 2001. Berman, Paul. "Pascal Bruckner." Suoth Central Review 24:2 (Summer 2007), pp. 56-53.

Bruckner, Pascal. "The Crises of Patriotism." South Central Review 25:3 (Fall, 2008), pp. 16-29.

. "Interview with Pascal Bruckner." South Central Review 22:2 (Summer 2005), pp. 11-19 
. Le Sanglot de l'homme blanc. Paris:Seuil, 1983.

. La tyrannie de la pénitence. Paris: Grasset, 2006.

. Le vertige de Babel. Paris:Arléa, 1994.

Colombani, Jean-Marie. "Nous sommes tous des Américains." Le monde, 12 September, 2001.

Glucksmann, André. "On Pascal Bruckner." South Central Review 24:2 (Summer 2007), pp. 26-30.

Todorov, Tzvetan. Les abus de la mémoire. Paris: Arléa, 1995.

. Devoirs et délices. Une vie de passeur. Paris: Seuil, 2002.

. "European Identity." South Central Review 25:3 (Fall, 2008). 16-29.

- L'homme dépaysé. Paris: Seuil, 1996.

. The Morals of History. Trans. Alyson Waters: Minneapolis: University of Minnesota Press, 1995.

. Le nouveau désordre mondial. Réflexions d'un européen. Paris: Laffont, 2003

- La peur des barbares. Au delà du choc des civilisations. Paris: Laffont, 2008. 


\section{The Francophone Writer at the Crossroads of Languages}

Peter W. VAKUNTA

Nazi Boni's Crépuscule des temps anciens is rich in several respects but the quality that captures the reader's attention the most is the writer's narrative style - the manner in which he indigenizes the French language to express Bwamu sociolinguistic reality. Boni makes ingenious use of language in an attempt to adapt French to the worldview, sensibilities and imagination of his native language. As Millogo puts it: "L'auteur opère un choix bien déterminé et bien frappant dans le matériau linguistique bwa...." (32). Though writing in French, Boni manages to produce a text that could be described as an indigenous language text written in French. By and large, he succeeds in doing this by having recourse to the technique of indigenization by which he imbues his text with Africanisms which add local color to the text and ascribe new significations to French words. Indigenization in this context deals with translating the worldview and imagination of Africans into a European language (Zabus, 1991, p. 23 ). This strategy fulfills the critical function of bridging cultural gaps in a multilingual communication context where indigenous and foreign languages jostle for space. As Gassama points out:

Il y a, en effet dans nos langues, des termes intraduisibles en français; les termes français correspondants ne satisfont pas toujours le romancier: si le terme français parvient à transmettre 
le contenu notionnel, il sacrifie les valeurs évocatrices du terme africain. (226)

Boni resorts to Bwa terms and expressions to fill these apparent gaps. For instance, he uses the word "Dô" or rite of passage, which could be translated as "rite" in French. However, he refrains from using the French word because the extra-linguistic connotations associated with the "Dô" rite of passage (e.g., social rank of the initiates, age disparity, etc) implied in the indigenous language term would not be conveyed in the French term. On this count, Boni deems it necessary to transpose the Bwa word into French. Indigenization occurs in the text through the transposition of vernacular words into the narrative as the following example shows: "Vous savez qu'on n'affronte pas ces épreuves en nombre impair sous peine de voir le plus jeune de la promotion avalé par le Dô" (113). In Bwamu culture, when the youngest participant in a rite of passage dies, it is said that s/he has been "avalé par le "Dô." Boni indigenizes the French word "avaler" by giving it a culture-specific signification. By having recourse to the technique of semantic shift, he ascribes a new meaning to this French word. In this context the word connotes "mourir". The narrator provides a succinct definition of the word "Dô" in the following excerpt: "Bien que Térhé fut le chef de file, il revenait à $B$ 'eeni de prendre la parole en sa qualité de fils du détenteur du fétiche des cultures: le Dô" (110). The term "Dô" is translated into French as "fétiche des cultures." The writer avoids a literal translation of the word, opting for a paraphrase. Characters associated with this rite are described using Bwa words namely, "yenissa" (118) [initiates], "bruwa" (111) [non-initiates] and "pamma" (111) [initiates in power]. The word "Dô" occurs repeatedly in the narrative and underscores the importance of this cultural practice for the Bwamu who perceive it as a "passation des pouvoirs" (163) or transfer of power. On the occasion of the "Dô" the "yenissa" are expected to hand over power to the "bruwa." Linguistic innovation plays a significant role throughout the novel - serving as a vehicle for the transposition of culture-bound concepts into the European language.

The presence of several indigenous terms and expressions in Crépuscule des temps anciens is an indication that Boni strives to bridge linguistic and cultural gaps in the act of storytelling. In doing so, he transgresses the normative canons of French grammar. All too often, he resorts to the use of native-tongue turns of phrase which may disconcert the Metropolitan speaker of French as seen in the following example: "Des générations étaient nées, avaient fait leur soleil et disparu" (19). In this excerpt, the word "soleil" acquires a new signification. In Bwamu, the word "soleil" 
refers to "epoch" or "era." Thus, the expression "avaient fait leur soleil" could be translated as "had seen their suns." Boni indigenizes the French language for the purpose of self-representation.

Literary indigenization fulfills didactic functions in the novel as well. Bwa metaphorical expressions present the reader with essential information on the belief systems of the Bwamu. For example, Térhé uses a proverbial expression to shed light on Bwa belief in common sense: "A refouler trop loin le crapaud on arrive à le remettre dans l'eau" (206). This proverb provides useful insight into the mindset of the Bwamu. It also crystallizes Térhé's character by throwing light on his inner-most thoughts and feelings about human relations. Sometimes, Boni uses native-tongue figures of speech for their persuasive value as this example shows: "La sagesse des Anciens nous apprend que Dombeni-Dieu-le-Grand ne crée jamais un oiseau sans l'avoir, au préalable nanti des moyens de trouver sa pittance" (22). This wise saying underlines the Bwa belief in the omnipotence of God.

Crépuscule des temps anciens is a classic example of contemporary African prose literature that underscores the cultural specificity of the context of creative writing as seen in the act of naming. Onomastics bears a stamp of cultural identity in the narrative. As Washington observes, "At birth, the child receives a name which is in direct relation to life forces associated with his clan's frame of reference. The name is conceived of as designating a real ontological individuality and expresses the very nature of the person" (cited in Julien 119). Names are meaningful appellations whose connotations may remain oblique to readers who do not belong in the cultures in which such names are used. Like Kourouma (1970), Boni uses the art of naming to communicate significant cultural messages. Most of the names he uses are of Bwa origin: Térhé, Kya, Lowan, Hadonfi, Hakani, Gnassan, Nazouko, etc. Proper names are used in several ways and for different purposes. Some serve as comments on the name-bearers. For example, Kya is translated as bero, that is to say, someone who kills with impunity. It is may be difficult to find equivalents for these names in European languages on account of disparities based on lived experiences. For example, the white colonizers are called "Nansara" meaning "inhabitants of the sky" or "sky people" on account of their association with the airplane as the following passage shows: "Il parait que la cornubation de Bonikuy a reçu la visite d'un homme phénomenal descendu du ciel: un homme tout rouge, avec de longs cheveux noirs, en brousailles: un Nansara"(215). Throughout the narrative, the word "nansara" is used as a synonym for "ennemi" because the Bwamu could not "tolérer que 
les Nansarawa après s'être insidieusement installés sur la 'Terre de leurs Ancêtres', se comportassent en maîtres, forts de l'appui de certains renégats autochtones" (222).

Boni also resorts to indigenous language words to categorize fauna as seen in this example: "Sa boueuse excellence $M b$ 'woa Gnoundjoa, le 'cheval aquatique "dont le ventre traîne à terre, y allait siester dans la fraîcheur marécageusse après avoir fauché le riz plantureux et les herbes rivulaires" (25). The term Mb'woa Gnoundjoa is the Bwamu term for "hippopotamus." In some instances, names translate respect due to age. For example, the title "Mb'woa" is given to people of a certain age. It could be translated as "grand-père" or "ancêtre" (Millogo 261). For instance, Mb'woa Gnassan is called "knife-bearer" in the following passage: "On commençait à s'impatienter quand arriva, suivi de son suppléant, le 'porte couteau', et de son héraut, un nonagénaire grand, nerveux et sec. Un murmure de respect parcourut la foule: Mb'woa Gnassan!!! Mb'woa Gnassan!!!"(42). It is clear from this passage that Mb'woa Gnassan is a noble - he has a retinue, comprised of a messenger and lieutenant. Above all, he is given the honorific title "knife-bearer," which ranks him among the privileged in the community. This is cultural information that Boni transposes into French by having recourse to the device of indigenization. Sometimes, Boni gives the name "Mb'woa" to astral bodies. For example, he refers to the moon as "Mb'woa P'hihoun" as the following sentence shows: "Emmitouflée dans son pagne de lumière Mb'woa P'hihoun, la Lune, passait en revue l'armée des étioles" (35). The personification of the moon in this passage is culturally significant that given the Bwamu believe that people's lives are controlled by celestial bodies. The attribution of human qualities to astral bodies suggests that the Bwamu maintain a symbiotic relationship with these bodies. Names, therefore, express both cosmological and ontological beliefs of the Bwamu. These examples go to show that Crépuscule des temps anciens could be considered an ethnographic novel on account of the cultural functions Boni assigns to language.

The most impressive quality of this text is the novelist's experimentation with language. His success resides in his ability to fashion out a hybrid language through the fusion of Bwa and French terns and expressions. As Millogo puts it, "L'auteur chante sa culture dans une oeuvre d'expression française certes, mais savamment et artistiquement construite à partir des langues et des sensibilités bwaba et française" (96). The "bwamufication"। of French in this text is achieved mainly through the technique of semantic shifts, a process whereby "[...] la signification des mots bwamu est 
systématiquement donnée en français selon les procédures nombreuses et variés de traduction, de reformulation et de construction de contextes de significations" (Millogo 100). Put differently, Boni employs African words and expressions bearing extended meanings.

Relexification enables him to play the role of a 'culture broker'. In other words, he succeeds in explaining Bwa cultural concepts in a language that did not create those concepts. The entire novel reflects his extremely rich knowledge of Bwa oral traditions. "Bwamufication" endows his text with a character that helps maintain a close bond between traditional verbal arts and the written word. As Ladmiral puts it, this writing technique " $[\ldots]$ produit un texte-cible sémantiquement, stylistiquement, poétiquement, rythmiquement, culturellement, pragmatiquement [...] équivalent au texte source" (cited in Millogo 60). Various forms of traditional verbal arts, including chants and songs are used by Boni as anchorage for his writing. It is perhaps for this very reason that his novel could be described as a kind of audible palimpsest. Genette argues that a text like Boni's could be seen as "[...] la vieille image du palimpseste, où l'on voit, sur le même parchemin, un texte superposé à un autre qu'il ne dissimule pas tout à fait, mais qu'il laisse voir par transparence"'(41). Thus the palimpsest is an attempt at getting rid of that which pre-existed in an attempt to write anew. Boni's desire to construct a French language text with a Bwamu cultural substratum remains visible throughout the narrative as seen in his use of ideophones

Bwa ideophonic expressions are transposed into the novel in an attempt to imbue the text with expressive vividness. Ideophones convey ideas relating to sounds, color, taste, and emotions as seen in this passage: "Térhé, tu es le dieu de la danse. Quand brille l'éclair, les hanwa s'écrient: 'Weeyo!' se tournent vers toi et te supplient: 'Beau gars, donne la réplique, danse et brille après l'éclair, comme un couteau d'argent [...]" (148). The expression 'Weeyo!' is an interjection signifying supplication. The hanwa (women) are entreating the formidable dancer, Térhé, to outperform the others. The expression that conveys the strongest feeling of emotion in this text, however, is wéée! This cry of desperation from a cuckolded husband is remarkable in the following passage: "Alors le malheureux conjoint se rendit compte de l'horreur de sa situation et poussa un wééé de désespoir, car il était à la merci de son antagoniste" (69). The ideophone "wéée" modifies the verb "poussa," giving it a specific meaning. These interjections serve as excellent examples of the indigenization process that is taking place in the text. The writer interpolates Bwa words into French and expresses the feelings of the Bwamu in this European language. $\mathrm{He}$ 
employs indigenous language interjections to imprint his text with the speech mannerisms of his people.

This switching of codes enables him to give prominence to the Bwa language in his text as the following example lucidly shows: "A chaque cérémonie funéraire, le ti'mbwani commence toujours par évoquer ce souvenir: Bwan-loho Nihi'nlé 'ville de Bwan, mortalité'" (47). Boni juxtaposes Bwa words with their French language translations: "Bwanloho Nihi'nlé" is rendered in French as "ville de Bwan, mortalité". This writing technique is reminiscent of Birago Diop's style in Les contes d'Amadou Koumba (1961). Like Diop, Boni writes: "Je t'écorcherai jusqu'à l'heure où Kobê-le-coq interpellera sa mère. Seule Humu-la-mort m'imposera le silence" (49). The word "Kobê" is the Bwa equivalent of the French word "coq". In a similar vein, the Bwa word "Humu" translates the French word "mort". A critic of Boni's novel may question the rationale behind the simultaneous use of synonymous words. The text is filled with such artful lexical juxtapositions. Sometimes, the writer uses the technique of language mixing to familiarize the reader with the religious beliefs of the Bwamu as this example shows: "Les Nanyê-Kakawa étaient des hommes-génies. Innombrables, ils se montraient uniquement à ceux qu'ils honoraient" (25). By having recourse to the technique of "Bwamufication" Boni transposes Bwa lexes into the French language. As Millogo points out: "Les éléments de la langue bwamu s'incorporent au français par la voie de l'écriture" (41). Lexical reformulation makes this incorporation feasible. Reformulation enables Boni to integrate Bwamu syntactic structures into French as seen in the following sentence: "Son seul nom semait la terreur. Pour inciter les malfaiteurs à parler bwamu, c'est-à-dire franchement pour les contraindre à avouer leurs forfaits, on menaçait d'appeler sur eux la 'sanction de Kya'" (63). The expression "parler bwamu' is a calque on the French expression "parler franchement." Boni restructures hackneyed French expressions to imbue them with new meanings as seen in this example: "Elles resteraient jusqu' aux calendes bwa" (150). The expression "rester jusqu'aux calendes bwa" is a reformulation of the French expression "renvoyer ou remettre aux calendes grecques". Syntactic reformulation may obfuscate comprehension for readers unfamiliar with the Bwa language and culture. To remedy the situation Boni often uses footnotes to shed light on words he suspects may constitute a stumbling block to the reader. Such is the case with the word "kata" which he translates as "lit de bambou ordinairement appelé tara" (51). These examples lend credibility to the claim that Crépuscule des temps anciens is a text steeped in the native culture of its author. 
It should be borne in mind that what Boni does in his text is a far cry from interlingual translation - the matching of lexical items in the source text with equivalent lexical items in the target text. He seeks to achieve intralingual translation, a process that enables him to transpose the worldview and sensibilities of the Bwamu into French. In other words, he expresses himself in a European language but in a manner consonant with the idioms and structure of an African language. In actual fact, what he engages in is communicative translation which enables him to translate not words but the imagination of the Bwamu into the French language. A classic example is the expression "boire à la gourde des fous" used in reference to someone who is mentally deranged as this passage shows: "Mais non! Tu déraisonnes; on dirait que tu as bu à la gourde des fous" (41). The expression "boire à la gourde des fous" is a calque on Bwamu language.

Oftentimes, Boni resorts to the technique of transculturation to underline cultural specificities as seen in this example: "De son côté veillait Gnoundofini, 'dieu de la tête' ou dieu individuel qu'il faut assimiler à l'ange gardien des Mon-père-wa et des Nasamuni-wa (28). In this sentence, the novelist adumbrates the Bwa concept of a "personal god." $\mathrm{He}$ starts off with the vernacular language word "Gnoundofini" but sensing that his non-Bwa readers may have difficulty understanding it, he translates it as "dieu de la tête." Not entirely satisfied with the translation, he renders it as "dieu individual." Of particular importance is Boni's neology in the sentence above. He creates words such as "Mon-père-wa" and "Nasamuni-wa" which he translates in a footnote as "Pères-blancs des missions catholiques" and "pasteurs protestants" (28).

Quite apart from neologisms, Crépuscule des temps anciens abounds with proverbs that illuminate the mindset of Boni's characters as seen in the following example "La lapine ne donne pas le jour à de courtes oreilles" (67). This proverb is used by the narrator to dwell on the comportment of Hakanni who breaks her clay pot when teased about her love for the protagonist, Térhé. Her action is likened to that of her mother who did likewise in her teens. The proverb is meant to translate the standard French expression, "tel père, tel fils." Proverbs do not only convey cultural information; they fulfill a moralizing function as this example illustrates: "Quand un enfant a les mains propres, il prend ses repas dans le cercle des Anciens" (81). The desire to teach is manifest in the novel's preface where Manessy puts emphasis on the "souci didactique" of Nazi Boni (13). Some of the proverbs convey sexual innuendoes as the following example indicates: "Une brise bienfaisante caressait les corps, réveillait 
les sens et décuplait la puissance de l'imagination. N'est-il pas vrai que Yohoun, 'Sanctuaire aux reflets d'argent', s'étiole à l'abri de l'air et de la lumière" (54)? The word "yohoun" is a euphemism for a woman's private parts. Out of fear of hurting the sensibilities of his readers, the novelist opts for what he considers a benign word. This paraphrasing technique enables him to name an object without classifying it. Paraphrases used in this text fulfill three functions - definition, precision and specification. Boni's intention to superimpose his native tongue on French is evident from the translation activity that goes on in the text. There is no easy way of dissociating the use of indigenous words from the thematic importance they convey. Bwa words vie for space with French words, leaving the reader with the impression that Boni is constantly negotiating linguistic and cultural spaces in the act of storytelling. As Sissao aptly puts it: "Cette prise en charge des termes de la langue bwamu, expression d'un ancrage culturel bwa très marqué correspond à des spécificités thématiques" (74). Metaphorical expressions raise ontological questions in the text as the following example lucidly shows: "L'enfant peut toiser la lune, mais pas le soleil" (125). The trope of an imprudent child defying the moon says a lot about the Bwa cosmological belief in symbiotic coexistence between humans and celestial deities in ordinary times and on ceremonial occasions.

The description of ceremonies marking marriage, initiation, birth and death are rendered vivid through the use of appropriate Bwa words and expressions as seen in this example:

Quand la nuit tombait, tout le Bwamu luttait, dansait, chantait en s'accompagnant des tianna, xylophone de paille, des poropinis ou flutes, des wi'zawa ou fifres. La mélodie des kokonis genre de harpes, se mélait à la symphonie de kondios, guitaires à cinq cordes .... Tout jeune homme devait savoir manier avec aisance plusieurs instruments de musique, particulièrement le tian-houn, le kondio, le kokoni, le win'za et toutes les variétés de konkoans ou trompettes. Le tiohoun communément appelé balafon, le donkoho, minuscule tambourin de guerre à la taille de guêpe, le kere 'nko, gigantesque donkolo, le kankan, tambour ventru, le ziri'nko, énorme kankan funéraire, constituaient - et constituent encore [...] des instruments réservés aux chanteurs et compositeurs traditionnels: les kakawa. (30-31)

Although some critics may fault Boni for overloading his text with indigenous language terms (Gassama, 1978, p. 223) it should be noted that indigenization does not constitute an encumbrance to the reader because the writer achieves a smooth transition from the indigenous to the European 
language. The novel seems to owe a lot to the semantic importance of the native tongue words he carefully chooses. For example, themes conveyed through words like "Dombeni", "Yunu" "Dô", "Nansara", and "Bwamu" constitute leitmotifs in the entire narrative. The word "Bwamu", for instance, is a word with multiple but related meanings. "Bwamu", is used in relation to the community of Bwa people, their language, worldview and sensibilities. The term is a hyponym of some keywords in the text, notably "Yunu"and "Dô." The novel could be interpreted as the thematic expansion of these keywords that enable the novelist to accomplish his task of indigenization [a process Zabus defines as: "the writer's attempt at textualizing linguistic differentiation and conveying African concepts, thought patterns and linguistic concepts through the ex-colonizer's language" (23)] as seen in this example: "Un devin, un jour remit au jeune homme un oeuf. Il lui spécifia que cet oeuf contenait sa 'silhouette', c'està-dire son double, plus exactement Mako son âme"(67). Faced with the difficulty of appropriately expressing the concept of "double" in French, the novelist tries to resolve the problem by falling back on the nativetongue word "Mako." His desire to express his Bwa imagination in the French language is achieved though a loan translation which serves as a technique for transplanting indigenous knowledge into a foreign language. Through the mechanism of indigenization Boni is able to appropriate the French language. Occasionally, he reproduces indigenous language terms in French because of their picturesque value as seen in this example: "Un frisson me parcourt le corps. Je serrai instinctivement autour de ma saignée, Yaro, mon gris-gris de chasse" (177). As this sentence indicates, fetishes are part and parcel of the lives of the Bwamu. Each hunter possesses his own fetish. Boni does not provide a physical description of the fetish. He only states that it is a solid object carried by the hunter on his body, adding that there are good and bad fetishes.

Indigenization is accomplished with such dexterity that the reader hardly feels any disjunction in the flow of the narration as the following passage indicates: "Kya était parti armé de son sabre, de son arc, de son woro. Il était parti pour une destination inconnnue. Personne ne s'inquiétait. N'était-il pas un béro"(64)? The word "béro" is brought into the narrative after the writer has shed light on the paraphernalia and attributes of a "béro". Boni spares the reader the trouble of having to read cumbersome definitions of unfamiliar words. Military exploits are not the preserve of natives in this text. The nansarawa too are portrayed as great warriors as this passage shows:

Le thème des conversations fut la 'Force' des Blancs que les Bwawa considéraient comme de mauvais génies descendus du ciel. 
La preuve, soulignaient-ils gravement, ce sont leurs amphores qu'aucune main humaine ne saurait façonner, et surtout leurs Kâayâwa ou canons qui tombent comme Karanvanni et crachent du feu comme le tonnerre. Leurs preinprein - fusil Lebel qui distribue la mort à trois mille enjambées à la ronde" (221). Words like "Kâayâwa", "Karanvanni", and "preinprein" are indigenous words used simultaneously with their French language translations. Boni's text is replete with bilingual constructions like these. He embellishes his text with Bwamu words each time he deems it necessary to do so as this other example shows: "Si j'avais retardé son yumu, ses obsèques, c'était parce qu'il convenait de choisir un moment favorable ... Il faut que son yunu revête une ampleur répondant à son passé de héros" (44). Boni places the word "obsèques" side by side with the Bwa word "yunu" for the purpose of clarity. This technique of interpolation enables him to underscore the cultural backdrop against which his text is written. The word "yumbeni" plays a similar role in the text given the close semantic affinity it has with the word "yunu" as seen in the following sentence: "Il faut que toutes les filles de Bwan, vieilles ou jeunes, mariées à l'extérieur, leurs enfants et les enfants de leurs enfants assistent au Yumbeni de l'Ancêtre Diyioua. Il faut que tout le Bwamu soit "versé' ici" (44). The speech pattern in this example is clearly Bwamu as the expressions "leurs enfants et les enfants de leurs enfants" (grandchildren) and "Il faut que tout le Bwamu soit "versé" testify. As a matter of fact, the village Ancestor Gnassan is appealing to the daughters of Bwamu to come in their numbers to the funeral of their Ancestor, Diyioua. The significance of this appeal becomes all the more evident when Gnassan adumbrates in the following terms: "Ensemble, nous mettons, aujourd'hui, en route pour Nihamboloho, le séjour des morts, un homme aux exploits fabuleux, l'Ancêtre Diyioua"(85). Boni artfully translates the Bwamu word "Nihamboloho" by placing it adjacent to its French language equivalent "le séjour des morts." Thus the writer's endeavor to negotiate linguistic and cultural spaces is evident.

The most striking aspect of Boni's style of writing is his determination to write Bwamu through the medium of French. This technique renders his indigenization process hitch-free as seen in his attempt to shed light on the Bwa concept of 'Lokoré': "Mais que vois-je? Une tourterelle qui tournoie dans la chambre du malade. Makô, l'âme de Térhé a déjà quitté son corps. Térhé n'est plus que sa simple envelope, je veux dire qu'il ne lui reste que Lokoré, la carcasse. Sa 'paille est presque consumée" (240). The Bwa term Lokoré translates the French word "carcasse." By providing a translation, Boni gives the impression that the French language equivalents 
are not rich enough to convey the latent meanings underlying indigenous language terms. The immortality of the spirit is underlined metaphorically via the expression "une tourterelle qui tournoie". The "Africanization" of French in the novel is impressive.

Recourse to "Africanization" as a narrative technique serves as an indication that the matrix of the text is African culture. In fact, throughout the novel, the writer resorts to borrowings from his native culture relating to divinities, rituals, rites and fauna. For example, "Dombeni" [God the Great], "M'Bwoa Samma" [elephant], "Tiohoun" [balafon],"Hunu" [death], "Kobê" [rooster], "Hanwa" [women], "Bawa" [men], "Yunu" [funeral], "Yenissa" [elderly people], "Brawa" [young people], "Mb'woa" [Ancestor], "Dô" [rite of passage], "Nimisis"[ Neveux], and so forth. These examples lend credence to the contention that Crépuscule des temps anciens is a novel calqued on the Bwamu language. To give the reader an insight into the concept of Bwa filial relationships, for example, the writer juxtaposes indigenous and French language words as seen in the following passage:

Les Nimisis ou "Neveux," les enfants des soeurs, c'est-à-dire tous ceux dont les familles maternelles sont originaires de Bwan, ont plein droit de se les approprier. Ils ne peuvent prétendre à l'héritage de leurs oncles, mais en revanche, sont autorisés à rafler leurs biens dans certaines circonstances (74).

The word "Nimisis" is translated as "Neveux." Although Boni endeavors to provide translations for native tongue words to facilitate understanding, the mere insertion of these words into a European language text constitutes an act of subversion in itself. As Kane points out, Nazi Boni is among francophone writers " [...] celui qui témoigne le mieux de la difficulté mais aussi de la volonté d'utiliser une langue qui tente d'exprimer de façon satisfaisante l'imaginaire de son ethnie qu'il entendait valoriser" (80). Boni sets out to write in French but realizing that this European language was inadequate to convey his Bwamu worldview, he deems it necessary to translate his native tongue into French. He exploits the rich traditions of his people to provide a cultural backdrop against which the text is written. For example, marriage is of such critical importance to the Bwamu that he infuses his text with vernacular language terms relating to matrimony as seen in this passage: "Il fallait danser $b a \hat{k} a$, la danse du mariage. Il fallait danser cette victoire, signe avant-courrier de la promotion des jeunes" (130). He explains that the bakka is generally intercepted by ululations called Ha huâaba! Lêlêlêlê (129), or nuptial ululations: During marriage ceremonies girls in their teens execute a lewd dance 
called the yenye: "Yenye, la danse des jeunes filles se déroulait dans une ambiance de vertige" (136).

Boni makes use of indigenous language terms to explain lived experiences that are, perhaps, unknown to the Nansarawa, especially the concept of slavery, known as Wobamu in Bwa language as the passage below illustrates: "Alors les Anciens jurèrent qu'au grand jamais la profanation de la 'Terre des Ancêtres' ne les trouverait ou ne les laisserait vivants. Plutôt Humu-la-Mort que Wobamu-l'esclavage"(233)! The word Wobamu translates "l'esclavage" just as Humu renders "la mort." From the beginning to the end, the narrative is spiced with Bwa terms and expressions. Concerning Boni's recourse to translation as a literary device, Gassama makes the following observation:

Il n'y a pas une seule page de Crépuscule des temps anciens où l'on ne rencontre une expression ou un mot africain ou une tournure de langue maternelle judicieusement ou maladroitement transposée en français. Du point de vue de l'apport de notre littérature romanesque à l'enrichissement de la langue française, Crépuscule des temps anciens est certainement notre roman le plus riche (223).

Boni's choice of words is not gratuitous. As Bonou points out: "C'est un moyen pour démontrer que les langues africaines sont riches et qu'elles permettent d'exprimer toutes les réalités. Ce qui fait l'originalité de Nazi Boni, c'est cette symbiose entre l'oeuvre et les réalités socio-culturelles du milieu" (57). Each term or expression is selected with due regard not only for its expressiveness but also for its appropriateness to the themes and contexts of communication. It is for this reason that Sanwidi contends that "Crépuscule des temps anciens se révèle à la lecture une mine d'une grande richesse [...]" (53) The novel is rich linguistically and aesthetically as the foregoing analysis succinctly illustrates.

The urge to appropriate the language of the ex-colonizer in Crépuscule des temps anciens is non-negligible. The desire to use translation as a writing device is manifest throughout the text. Through the technique of translation, Boni is able to transpose Bwa culinary terms into French as seen in the following passage: "Quel plaisir de se retrouver autour des plats de doro et de sauce épaisse, de pois gras, de mil bouilli brassé à la pâte d'arachide, de gnonkon, mélangé de repasse et de légumes verts cuits à l'étouffée, arrosé de beurre et fortement assaisonné"(37). In this passage, the novelist introduces the reader to two Bwa dishes: "doro", a delicious meal made of millet and "gnonkon" - a dish comprising green vegetables, mixed with butter and spices, generally cooked in a tightly 
shut pot. He adds that a meal of "gnonkon" is never complete until it has been "washed" down with a bowl of locally brewed beer called "gnamu": "Apprêter le fonio, le riz, la farine de mil ou de maïs, préparer en quantité industrielle un gnamu sirupeux — bière de mil qui colle aux lèvres [...]" (53). This passage exposes the reader to three basic Bwa culinary terms - "doro", "gnonkon" and "gnamu". This sort of linguistic innovation accounts for the aesthetic richness of Boni's novel.

In this paper I contend that postcolonial Francophone African literature is characterized by linguistic innovation, a device that enables writers to employ the language of the ex-colonizer to interrogate the hegemony of colonial cultures. By having recourse to the technique of indigenization, Boni calls into question some of the assumptions associated with cultural imperialism, notably the predominance of the French language in Francophone literary discourse. He indigenizes his text by having recourse to appropriation strategies in ways that transgress the canons of standardized French usage. By indigenizing the French language, he creates a hybrid text that demands of its readers to be not just bilingual but also bicultural. A problematizing of language and narrative techniques are central to my reading of Crépuscule des temps anciens. The contextual function of language is critical to the understanding of the novel. There is no doubt that as a creative writer Boni straddles two worlds, constantly negotiating space to wed the French language to the rhythms of African speech. Bestriding two cultural spheres, he is virtually at the crossroads of languages. He cannot be faithful to the one without betraying the other. Like the polygamous husband in a dubious romantic relationship, Boni is obligated to make love with both his "wives" - French and Bwamu.

\section{Note}

1. Interpolation of Bwa language words and expressions into an African text written in a European language.

\section{Works Cited}

Boni, Nazi. Crépuscule des temps anciens. Paris: Présence africaine, 1962. Bonou Boniface. G. "Un Pionnier: Nazi Boni." Notre Librairie 101 (1990):54-57.

Diop, Birago. Les contes d'Amadou-Koumba. Paris: Présence africaine, 1969. 
Gassama, Makhily. Kuma: interrogation sur la littérature nègre de la langue française. Dakar: Les Nouvelles Editions Africaines, 1978 . La langue d'Ahmadou Kourouma ou le français sous le soleil d'Afrique. Paris: Editions Karthala, 1995.

Genette, Gerard. Palimpsestes: la littérature au second degré. Paris: Editions du Seuil, 1982.

Julien, Eileen. African Novels and the question of Orality: Bloomington: Indiana University Press, 1992.

Kourouma, Ahmadou. Les soleils des indépendances. Paris: Editions du Seuil, 1970.

Millogo, Louis. Nazi Boni, premier écrivain du Burkina Faso: La langue bwamu dans Crépuscules des temps anciens. Limoges: Presses Universitaires de Limoges, 2002.

Sandiwi, Hyacinthe. "Depuis le crépuscule des temps anciens : panorama du roman." Notre Llibrairie 101 (1990):48-54.

Sissao, Joseph A. "La question du métissage dans l'écriture du roman burkinabè contemporain." http://etudesafricaines.revues.org/ document 121.html?format=print

Zabus, Chantal. The African Palimpsest: Indigenization of Language in the West African Europhone Novel. Amsterdam: Rodopi, 1991. 


\section{The Weight of Secrets: Hidden Mirrors of Identity in Aki Shimazaki's Pentalogy}

Peter SCHULMAN

In Tsubaki, the first of Aki Shimazaki's series of five novels, a Rashomon'-like pentalogy in which the same characters try to unravel the personal traumas of their lives right before the atom bomb hits Nagasaki, the city that they have just moved to, one of the main characters, Yukio, cries out: "Ce n'est pas le temps de chercher la vérité, c'est l'unité qui compte" (Tsubaki 53). In that instance, he was defending a young Korean unjustly accused of theft. Could the same be said for the rest of Shimazaki's novels? Indeed, in Tsubame, for example, the narrator, a Korean immigrant living in suburban Tokyo must hide her identity during the war to escape persecution and murder, has her name changed from the Korean Yonhi to the more Japanese-sounding Mariko, but continues her spiritual camouflage well after Japan's defeat in World War II to the point where her own family believes she is in fact Japanese. "Je ne parle à personne de mon origine," she explains, "Mon fils croit, comme autrefois mon mari, que ma mère et mon oncle sont morts pendant le tremblement de terre, en 1923. La défaite du Japon et l'indépendance de la Corée n'ont rien changé à l'attitude des Japonais contre les Coréens au Japon" (Tsubame 61). Shimazaki's main character is a crypto-Korean living in war-torn then post-war Japan while Shimazaki herself is a Japanese woman living in Canada but writing in French. Shimazaki's enigmatic Japanese titles to her books are indicative of her own idiosyncratic mise-en-abyme nar- 
ratives in which there can be several layers of identity hidden within the frames of language (French for Shimazaki, Japanese for her Korean-born characters living in Japan, and finally silence for the adulterous narrator of Hotaru). How does French function as a unifying mirror for these many layers of identity that are hidden throughout her novels? Could an Asian-Québecois public persona in a city as linguistically polarized as Montreal be a fitting depository for the secrets Shimazaki wishes to keep from her own Japanese past? Shimazaki's quasi-obsessive preoccupation with a single traumatic event viewed from many angles, and her elegant attempts to camouflage the secrets her characters with enigmas taunt her readers towards such questions. Indeed, her titles are all delicate, elegant origami-like metaphors for her characters' deep inner feelings (Tsubame means "Swallow", a metaphor for the flight the main character wishes to embark upon from her painful childhood; Hotaru is the "firefly" the narrator wishes to be at night when she is seduced by a selfish married man; and Hamaguri is a Japanese clam representing the shells the narrator and her mother try to put together to connect with as well as to shelter each other from the mother's wartime horror). "Je ne pourrai jamais avouer l'histoire de mon origine à mon fils et à sa famille," the narrator of Tsubame confesses, "Je ne veux absolument pas que notre vie en soit perturbée" (Tsubame 61). In what she chooses to reveal to her readers, however, Shimazaki pirouettes with language as well as collective and personal trauma to fulfill a type of unity within her writing: a unity similar to the string of shells the characters symbolically create in Hamaguri to protect themselves and others from both truths and lies.

"Le français m'a apporté la clarté et la précision," Shimazaki explains in an interview with François Dargent in Le Figaro. "Ce qui est à l'opposé de la mentalité japonaise" (Figaro 2).

Indeed, if Mariko's mother urges her daughter to never take freedom for granted, "rien n'est plus précieux que a liberté. N'oublie jamais ça, Yonhi" (Tsubame 20), French may have given Shimazaki a freedom of creative expression that enables her to see her country of origin with more clarity and direction that she might have had she written her novels, which are all set in Japan, in Japanese. Shimazaki, who now teaches Japanese and translates in Montreal, has been writing in French for the past fifteen years after having lived in Vancouver and Toronto briefly. It took her just under six years to complete each of the five novels: Tsubaki, le poids des secrets (1999); Hamaguri (2000); Tsubame (2001); Wasurenagusa (2003); Hotaru (2004). She has in fact followed a long line of great authors who have adopted French as their literary language of choice. If famous, now 
canonic writers such as Ionesco, Beckett, and Kundera all wrote their masterpieces in French rather than in their native tongues, Shimazaki now joins a whole new generation of successful writers who have done the same today. Recently, the Goncourt prize had been awarded to Tahar Ben Jelloun, Amin Maalouf, André Makine, and in the last two years, the American Jonathan Littell and the Afghan Atic Rahimi who broke from his native Persian in order to find the right voice for Singué Sabour. "Au depart, je ne me posais même pas la question, je n'y pensais pas," he reminisces to Dargent. "Quand je suis retourné dans mon pays en 2002, j'ai retrouvé ma culture...et l'envie d'écrire en français. Singué Sabour, pierre de patience est sorti directement en français. En fait, il m'était difficile - je ne sais pourquoi- d'aborder ces sujets importants, tabous, dans ma langue maternelle. La langue française m'a donné la possibilité de m'exprimer avec une certain liberté" (Figaro 2). For Shimazaki, the moment she knew she wanted to write in French came after she read the work of Hungarian author Agota Kristof who also chose to write in French. It was after having read his novel, Le grand cahier, that Shimazaki decided to make French her adopted literary language: "J'ai été fascinée par son style très simple et son histoire si profonde. A cette époque, $j$ 'avais déjà des idées pour mon roman Tsubaki. Alors, j'ai decidé de l'écrire directement en français. Il m'a fallu trois an pour l'achever" (Figaro 3).

Although one can read the novels of the pentalogy in any order as each story can be approached on its own merits, it is easy to get tangled in the narratives as each one represents a particularly intense search for individual identity, resolution or absolution that is nonetheless interwoven into an original relationship matrix set off by Mariko, the mother and grandmother of several narrator/protagonists and Mr. Horibe, a lecherous married man she has an affair with. Moreover, the pentalogy is also highly engaged in the violent upheaval within the historical narratives of war-torn and post-atomic Japan. The first novel in the series, Tsubame, for example, begins with the death of Yukiko, who reveals the secrets of her tormented life in Nagasaki during World War II through a long, confessional letter; Hamaguri is written from the point of view of Yukio, Mariko's son, who slowly reveals his poetic friendship/love for Yukiko when they were both children and each of their parents would take them to the same park. There they made a loyalty oath to each other which they inscribed in a clam shell. Once they become adolescents, they find themselves in Nagasaki without recognizing each other. During the last hour of her life, Yukio's mother retrieves the clam shell for her son, and opens a floodgate of memory during which he realizes he is Horibe's illegitimate son, and Yukiko is his 
half-sister. In Tsubame, Shimazaki firmly places her narrative within the horrors of the catastrophic 1923 Tokyo earthquake which caused 140,000 deaths. It is during that brutal chaos that Mariko must take on a Japanese identity as the Japanese were unleashing a murderous racist onslaught towards Koreans living in their country. Towards the end of her life, as a widower, mother, and grandmother of three, she learns the truth about her identity and the catholic priest who protected her after the earthquake and saved her life. In Wasurenagusa, the narrative voice shifts to Kenji Takakashi who married Mariko and adopted her son Yukio. After a failed first marriage, and after learning that he is in fact sterile, he falls in love with Mariko against the wishes of his parents who frown on her situation (a single parent of an illegitimate child) and disown him. His only attachment is to Sono, his nurse growing up. Forty-six years later, retired and frail, he decides to seek Sono out. When he tracks down her gravesite, he too discovers his own secret identity and learns of how the vicious Horibe had him transferred to Japanese-occupied Manchuria during the war to keep him away from his mistress Mariko whom he continued to desire. When the Russians overrun Manchuria after Japan's collapse, he is sent to a labor camp. He also finds out that he too was adopted and that Sono was his real mother. In Hotaru, the last novel in the series, Shimazaki ends with the event that spawned the rest of the books, Mariko's early relationship with the married Horibe who selfishly tries to control her as his mistress. The last novel is told from Mariko's granddaughter's point of view as she learns of her grandmother's past. Little by little, in a manner similar to the reader's experience with the pentalogy, Mariko confides in her granddaughter and reveals the ultimate secret of how Yukiko poisoned her own father with cyanide right before the atomic bomb hits Nagasaki when she found out how he had treated Mariko. When Kenji Takahashi remembers hearing someone ask him once "Vous êtes d'origine douteuse, n'est-ce pas?" (Wasurenagusa 84), he could very well be hearing an echo of the subconscious doubt that haunts each generation of characters from grandmother to grandchild through the five novels.

While the series of books Shimazaki writes unify all the characters within a similar trauma, the horrors of World War II, each of the protagonists suffers personal trauma as a result of one fundamental adulterous relationship, and the fruit of that relationship, an illegitimate boy who must continuously question his own roots. His half sister, who shares the same father as the boy, Mr. Horibe, is also linked to the series of anguished relationships. As Paul Ricoeur has suggested in regards to collective memory and its parallel phenomenon, collective oblivion, personal trauma is 
often engulfed by collective ones as well: "Ce n'est donc pas avec la seule hypothèse de la polarité entre mémoire individuelle et mémoire collective qu'il faut entrer dans le champ d'histoire," Ricoeur writes, "mais avec elle d'une triple attribution de la mémoire: à soi, aux proches, aux autres" (Ricoeur 163). As such, in Tsubame, we learn that much of Shimazaki's ensuing pentalogy rests upon several layers of hidden identities and events that only a single document, a diary written in Korean by the narrator's grandmother, is able to unravel and reveal. In addition to the horrors of illegitimacy, the narrator, Mariko, is also shrouded in the mystery of a collective past: the plight of Koreans living in Japan in the early twenties (and even today). Known as Zainichi, Korean-Japanese have suffered untold racism and feelings of unworthiness that Melissa L. Wender has described in terms of "lamentation as history" in her book of that title and what the famous Japanese critic Eto Jun has labeled "maturity and loss" in his analysis of Zainitchi literature. Throughout the $20^{\text {th }}$-century, regarding that work, Wender remarks, "although the subtitle to Eto's book is 'The Decline of the Mother,' the work in fact deals almost exclusively with the loss of authority of the father in postwar Japan" (Wender 216n14). Within this context, one can also read Shimazaki's pentalogy in terms of the loss of paternal authority in the sense that Yukio never knows who his biological father is (even though he lurks very close by in order to extend his affair with Mariko). Moreover, we learn that Yukio's stepfather, Mr. Takashi, is in fact sterile in book five, Wasurenagusa.

As Seiju Takeda explains regarding the "Zainitchi condition," the "second generation of Zainichi [...] at some point must abandon an ideological desire for 'society' and land themselves in the order of personal life. Then the impulse to appear that abandonment through the narratives of 'the family', 'the history,' 'ethnicity,' 'nation,' is impressed upon them. What we must note is that the desire for 'reconciliation' with the 'father' or 'history' at this time in reality appears as a conflicting discourse with those "various ideologies"' (Wender 63). Just as Zainitchi were forced to be fingerprinted in Japan, and often had to change their names to Japanese ones, Shimazaki's characters bury their external traces of identity and leave only the metaphoric fingerprints of who they really are and what they want to be in the titles of each novel which, to Francophone readers, are nonetheless codified and secretive as they are all Japanese words. Similarly, each book is filled with so many Japanese expressions that they have a lexicon of terms at the end in order to give the reader an "Ariadne's clew" or a trace with which to navigate the daedalus Shimazaki's work progressively becomes. In this way, the five books represent five facets 
of a fragmented identity that is initially sparked by a historical trauma, the monstrous 1923 earthquake which Shimazaki represents as a type of holocaust as poorer neighborhoods are wiped out by flames and Japanese troops begin to randomly kill all Koreans as scapegoats and enemies of the people. As the narrator digs deeply into her childhood memories that had been thoroughly repressed, she remembers the smoldering houses around her and then the sudden spasm of violence against her people- just as they are in the most vulnerable and weakest of positions: "Soudain on entend des cris. Puis plusieurs hommes paraissent devant la foule. Ils ont un sabre, une lance de bambou, une gaffe. Je ne comprends pas ce qui se passe" (Tsubame 28). Through the child's eye filtered by memory and its companion, oblivion, the nonsensical brutality becomes clearer and clearer in her mind: "L'un des hommes dit: 'Arrêtez tous les Coréeens! Ils sont dangereux. Ils tentent de jeter du poison dans les puits/ La foule s'agite. Un autre homme lance: - Les Coréens mettent le feu! Ils volent à mains armée! Ils violent les femmes! Quoi? Je regarde ma mère. La bouche cousue, elle me fait signe de ne pas parler. Son visage est tout crispé" " (29-30).

If Wenders describes post-war Zainichi literature as "uncircumcised ethnicity" in reference to Moses's "uncircumcised lip" in the Bible (often interpreted as a stutter), the silence that the narrator must endure out of terror is only diffused years later through writing and metaphoric invention throughout the pentalogy. So great is the terror within the memory:

Le troisième homme dit: - capturez tous les Coréens sans exceptions! Les autres poussent des cris en agitant les armes. La foule panique. Je ne bouge pas. Tout mon corps frémit de peur. La femme au petit garçon nous regarde, ma mère et moi. Les hommes armées circulent entre les gens. L'un deux s'arrête devant ma mère, l'air soupçonneux. A un moment où il ouvre la bouche, la femme crie: "-Madame Kanzawa! Je ne savais pas que vous étiez ici." (30)

At the last minute, she and her mother are saved by a lie, a change of identity, and a change in family name. Similar to the Jewish Sally Perel, who in his World War II autobiography Europa, Europa reveals that, in parallel circumstances in Russia, as the Germans invade the USSR and interrogate him, he saves his own life by pretending to be Aryan and goes on to be assimilated by the Wermacht as a young Nazi soldier at the front. ${ }^{2}$ When, at the end of the episode in which they are saved, Mariko's mother declares, with tears in her eyes: "Il faut partir maintenant," she 
is also alluding to the spiritual departure that both mother, daughter and future offspring will have to undertake, not away from Japan towards the motherland, but far away from their authentic identities that must be buried within them as a security field against death in the immediate and, later, against racism and self-exile. As Lucie Lequin understands it, the trauma experienced by Shimazaki's characters is an especially collective one for Koreans in Japan as a result of the frenzied thanatos released after the 1923 earthquake. The Zainitchi found themselves trapped in a situation with no exit:

La différence poussée à son paroxysme est, dans le pire des cas, pour les uns cause de mort, pour les autres, cause de peur, de sentiment d'étrangeté et de mensonge puis cette différence, déterminée par la norme, tue. Cette "rumination haineuse" [selon Daniel Sibony] collective se fait conviction; elle est normale. Devant une telle haine maladive, les étrangers ou plutôt ceux qui sont étiquetés étrangers doivent donc se protéger, fuir parfois, ou encore se donner une identité qui n'est pas la leur. (Lequin 41)

In Tsubame, however, what identity must the narrator take on, in addition to a simply Japanese one? Indeed, all traces of her Korean past are erased, including heroic images of her activist journalist father who disappeared before she was born, and her uncle who fled repression in Korea only to find more horrific repression in Japan where he too will vanish after the earthquake. ${ }^{3}$ Moreover, as she explains, in addition to memory, she also loses the language of memory, her mother tongue:

Dix ans avaient passé depuis le tremblement de terre. Pendant cette période, je n'avais lu, ni entendu, ni écrit ma langue maternelle. Je n'étais plus capable de lire le Coréen, surtout du [...] journal [de ma mère] qui avait été écrit sous la forme cursive, utilisant beaucoup de caractères du hanmun (ideogrammes chinois). Je n'ai osé montrer le journal à personne pour en connaître le contenu. Depuis, je ne sais pas combien de fois j'ai été tenté de le brûler. Néanmoins, j'ai manqué le courage pour le faire. (Tsubame 60)

Taken under the wing of the European catholic priest who gives her shelter and takes care of other refugees and orphans, she admits to having forgotten all about her mother's diary: "La veille de notre départ, le prêtre $m$ 'a rendu le journal de ma mère que j'avais complètement oublié". $(60)$. Forgetfulness becomes not only a means for continuing to survive 
in war-torn and xenophobic Japan, but a necessity after the war as well. As Lequin explains, with forgetfulness comes life and new strengths with which to confront the past:

Shimazaki [...] fait place à la vie. Même si nombre de ses personnages et de leurs émotions trop longtemps retenues, Shimazaki tente de débusquer derrière les apparences, les blessures identitaires [...] Le travail de la mémoire se place au coeur de son récit, une mémoire singulière, intime, souvent encore voilée malgré une révélation partagée; cependant, contrairement aux derniers personnages de [Ying]Chen qui fuient le réel, les personnages de Shimazaki sont toujours fortement, de plein pied dans le contexte sociopolitique du Japon. (Francographies 108)

Years later, when the narrator joins a crowd as workers begin to unearth a mass grave of Koreans who died in the 1923 massacres, Shimazaki points to the collective memorialization of her trauma as she suddenly yearns and thinks of her mother's bones which might be buried there along with the other anonymous bodies:

J'écarquille les yeux. Je vois, sur la berge, une gigantesque fosse. On pourrait y mettre une maison entière [...] Autour de la fosse se tient un autre groupe de spectateurs. Au fond, plusieurs hommes grattent la terre des parois avec une pelle. Chaque fois que l'un d'entre eux découvre un objet, les gens en haut demandent en se penchant: "qu'est-ce que c'est? Peut être un os!"/Non - sans doute une pièce de verre. "Un os? De qui? De ma mère. De mon oncle..." (79)

The dig becomes a metaphor for her own impromptu digging through her memory and identity issues. It is as though Shimazaki were making a word play on fosse and fausse ("ditch" and "false" in French) in the sense that her true self and origins are being unearthed while her false-Japanese self watches in horror. As she observes a priest who looks down to the dig with a stern expression his face, she can't help noticing his racial characteristics:

Je regarde le visage du père. Les mains croisées, il observe sérieusement l'opération en contrebas. Ses paupières mongoles me rappellent les yeux de mon oncle. Je me demande un moment s'il est d'origine coréenne et s'il cache son identité à ses enfants parce qu'il est devenu japonais.... (79)

Her identification with the priest, "père," is, of course, within Wender's typology, a quest for the missing father that haunts all of 
Shimazaki's characters such as Mariko's son, Yukio, Mariko herself who is protected by the spiritual European father, but exploited by the lecherous adulterer Horibe who refuses to be his son's father by not marrying her; and the missing paternal authority of either the Korean or even the Japanese Fatherland which crumbles as Japan loses the war. When she overhears the priest discuss the various atrocities the Japanese committed after the earthquake, she cannot help becoming increasingly absorbed in the collective narrative of her past and her people: "Il y avait des centaines de cadavres laissés aux champs le cou coupé, le bras tordu, la tête fendue. Même celui d'une femme enceinte, le ventre ouvert, l'enfant visible. C'était une atrocité" (88). As she must decide whether to flee or stay and bury herself even more in stories and memories, she nearly faints, and longs so much for her mother and her maternal roots that she screams to herself hysterically, as the flowers she sees in some girls arms triggers an involuntary reaction: "En un instant je me dis: Maman! Je suis au bout des larmes. Mes pieds tremblent. La femme commence à fredonner la mélodie d'Ariran [la chanson de la Patrie]. Mes larmes tombent. 'Elle est là! Elle est revenue me chercher après cinquante neuf ans d'absence! Le bleu des campanoles brille sur la manche du chogori blanc"(81).

The discovery of buried corpses within Mariko come to the surface of the text just like the many hidden narratives that are interwoven throughout the five books, yet the unearthing of the ultimate secret about the mother's true identity is at the crux of all the different other strands of secrets that Shimazaki writes about. "Il y a des choses qu'on ne peut dire aux autres...", the mother of the narrator of Hotaru whispers at the end of the novel, "Garde cette histoire pour toi, s'il te plait" (129). Fortunately, not only does Shimazaki share the series of secrets with her readers, she also presents them through many facets, many layers, and many aesthetically pleasing "coatings" like the exotic and delicate creatures, flowers and objects that make up the title of each book. The return of the mother through the dig is thus a reconciliation of the different ghosts that haunt the five books that find a type of resolution through the decoding of the very concrete and definitive diary written in Korean, which serves as both a clandestine, and ultimately clarifying document. It is, in this way, similar to the recent instillation by Chantal Akerman, "Walking next to your laces in an empty refrigerator" ["Marcher à coté de ses lacets dans un frigidaire vide"] (2004, Marian Goodman Gallery, NY). As in Shimazaki's pentalogy, the central point of Akerman's instillation revolves around a journal written by her grandmother when she was a teenager in Poland. In the darkened room, texts written by the artist herself, are mixed with selected words from the 
grandmother's journal, and stream across the walls of a room-size spiral structure. As the program describes it: "Made of white, diaphanous material, the spiraling walls call to mind the properties of a screen or scrim, a skin, or even a bandage" (1). In Shimazaki's work, literary words and metaphors also serve as bandages and screens for unspoken tragedies. As Akerman states it, in terms that are parallel to Shimazaki's, "It started off with the journal, my grandmother's journal. The only thing we have left, my mother always says. Often I mull it over in my mind and I work with the notion of lacking, of nothingness [...]. Here, I worked with what we had left. Not much, yet an entire world" (Akerman 1).

While little is known about Shimazaki's own life (as she is very discrete) a part from the fact that she moved to Canada when was in her early forties, it is clear from her writings that she is nonetheless emotionally wedded to the untold stories and quiet sufferings within a Japan that is not always featured in History books (especially those printed in Japan). By confronting the plight of the Zainitchi, for example, or by examining the predicament of the Japanese who were left behind in Manchuria and sent to Soviet labor camps, or even by understanding the inner lives and dramas of ordinary citizens of Nagasaki before and after the atomic bomb hits their city, Shimazaki delves sensitively into the carefully hidden secrets of modern Japan itself. Writing from the origami-like "wrapping" that the French language and a Francophone readership can provide far from her native soil, Shimazaki can write with a sense of relative freedom from the controversies and debates fought by a Japanese public not eager to confront a slice of the past they would rather ignore. With the recent political tempests surrounding such issues as whether conservative Japanese politicians should be able to visit Yasukuni the national shrine where some war criminals are buried, or China bringing up the savagery of the Japanese army in Nanking, or even the now unearthed trauma of the Korean "comfort women" who were forced into Japanese army-run brothels, it would be understandable for Shimazaki to want to carve out a literary oasis for herself far from the possibly oppressive judgments of Japanese public opinion.

In her first novel after the pentalogy, Mitsuba, ("Clover"), Shimazaki does in fact confront the stifling realities of contemporary corporate life in Japan as she deconstructs an affair between a young "salary man," Takashi Aoki, and a secretary, Yûko, who wants to move to Montreal. Although he knows he wants to choose a life abroad with his "soul mate," he is nonetheless trapped by Goshima, the import-export company he works for. In keeping with similar themes in Shimazaki's work, the young man 
must learn to negotiate both his family's past we well as the weight of Japanese tradition. As his mother describes it when he tells her that he might be transferred to either Montreal or Paris:

- Tu t'amuses à travailler, ce n'est pas comme ton père.

Les temps ont changé.

Je me tais. Je me sens lourd en pensant à lui qui a été

chassé du Japon come je suis en train de l'être. Ma mère me regarde: [...]

- Paris ou Montréal, cela m'est égal. Les deux sont loin du Japon.

While the pentalogy focused mostly on the inner and outer struggles associated with the war and its aftermath, in Mitsuba, Shimazaki sheds light on the heaviness of contemporary life as well as the appealing aspect of an alternative land and society: francophone and bi-lingual Montreal. At one point, Yûko recounts the liberating sensation she feels in Quebec which she views as a parallel but ultimately freer universe compared to Kobe, the Japanese city she loves the most: "Elle avait gravi une pente qui menait au belvédère du Mont-Royal. 'C'est Kobe!' s'était-elle écriée. Au loin, elle avait aperçu le fleuve Saint-Laurent semblable à la mer intérieure de Seto. Devant le mont s'étendait la ville de Montréal semblable à celle de Kobe [...] De nouveau, elle avait eu l'illusion d'être chez elle" (Mitsuba 70).

Throughout the novel, the fantasy of escape that Montreal provided for the young salary man had been merged with his passionate love for Yûko whose seemingly courageous leap of faith away from the company and the security it provided could in fact have been an illusion as well. Similarly, Shimazaki's economical and poetic prose (author/artist Sienna Powers has in fact referred to Tsubaki as "Haiku in prose" in her review of that book), interspersed with numerous Japanese words also creates the "illusion" of having been written in Japanese. Yet it is also emblematic of a burgeoning Asian-Canadian literature that is spearheaded by Canada's surging Asian community. Writers such as the Chinese-born Ying Chen, or Korean-Canadian Ook Chung have also endeavored to come to terms with the tension between their respective "homelands" and new communities and mores. Yet, when in Mitsuba, Aoki learns that Yûko has not gone off to Montreal but has married an executive in her company instead, he suddenly gets the final burst he needed to break from his personal chains of tradition that had been holding him back. As he leaves his office for the last time, he tucks his badge in his pocket, as an act of defiance, on 
the one hand, and as a type of identity rebirth on the other: "Des piétons me jettent un coup d'oeil. Certains d'entre eux remarquent le badge de la companie Goshima attaché sur le revers de ma veste. Ils me regardent avec respect et envie. Je me retourne pour voir l'immeuble Goshima. Eclairées par le soleil, les vitres brillent. J'enlève le badge et le mets dans la poche intérieure de ma veste" (140). Just as Aoki can place his Japanese corporate identity in his inside pocket near his heart before undertaking a bold adventure, Shimazaki, through her concise yet mystery-laden writings, is also able to translate deep cultural rumblings into a unique art form.

When, at the end of Tsubame, Shimazaki's last image is of a little boy, "[L']enfant tourne la tête vers moi. C'est Yukio. Il agite sa main: 'Maman! Maman!'”, she seems to be passionately affirming that, despite the absence of many layers of fathers, the maternal world is ultimately the one she returns to and remains the only terra firma she can ever know.

\section{Notes}

1. Rashomon (Akira Kurosawa, dir, 1950).

2. Shlomo Perel, Europa, Europa. Traduit de l'hebreu par Lysette Hassine-Mamane. Paris: Ramsay, 1990.

3. Indeed, Sally Perel experiences a similarly shocking identity crisis in Europa, Europa when he realizes that he has suddenly been transformed into a German soldier: "Salomon, devenu Yop le soldat victorieux, et à present Josef de la Jeunesse hitlérienne, avait trouvé un camouflage idéal et y vivait en toute sécurité. Mais jusqu'à quand? Etait-il possible de vivre ainsi indéfiniment, avec une identité d'emprunt, sans papiers d'identité et avec une circoncision alors meme que ce régime veillait, jusqu'à la démence, à empêcher toute infiltration d'étranger au sein du people sur lequel il régnait de façon totalitaire?" (91)

\section{Works Cited}

Ackerman, Chantal. "Walking next to your laces in an empty refrigerator" ["Marcher à côté de ses lacets dans un frigidaire vide"] (2004, Exhibit presented at the Marian Goodman Gallery, New York City). Dargent, Françoise. "Le français, langue d'accueil de tous les écrivains du monde." Le Figaro. Livres. 01/08/09. www.lefigaro.fr/ livres/2009/01/08 pp. 1-4.

Jun, Eto. Maturity and Loss: The Decline of the Mother (Seijuku to soshitusu: 'haha' no hokai).(Tokyo: Kawade Shobo, 1967). 
Lequin, Lucie. "De la mémoire vive au dire atténué," Voix et Images. Volume 31, Issue 1 [91], 2005, pp. 89-99.

. "Aki Shimazaki et le plaidoyer de la vérité," Dalhousie French Studies, Volume 64, 2003, pp. 39-46.

. "L'Imaginaire des femmes dans l'écriture québecoise actuelle," Francographies, Numéro Spécial, 100ème anniversaire, Colloque 2004, Volume 1, pp. 101-110.

Perel, Shlomo. Europa, Europa. Traduit de l'hebreu par Lysette HassineMamane. Paris: Ramsay, 1990.

Powers, Sienna. "Haiku in Prose." Book review of Tsubaki by Aki Shimazaki translated by Fred A. Reed. Published by Talonbooks in January Magazine, July 2000. (www.januarymagazine.com/fiction/ tsubaki) pp 1-3.

Ricoeur, Paul. La mémoire, l'histoire, l'oubli. (Paris: Seuil, 2000) [Memory, History, Forgetting].

Shimazaki, Aki. Hamaguri. Montreal: Leméac/Arles: Actes Sud, 2000.

. Hotaru: Montreal: Leméac/Arles: Actes Sud, 2004. . Mitsuba: Montreal: Leméac/Arles: Actes Sud, 2006. . Tsubaki. Montreal: Leméac/Arles: Actes Sud, 1999. . Tsubame.Montreal: Leméac/Arles: Actes Sud, 1999. . Wasurenagusa. Montreal: Lémeac/Arles: Actes Sud, 2003.

Sidony, Daniel. Jouissances du dire. Paris: Grasset, 1985.

Takeda, Seiju. " 'Zainichi' to iu konkyo' in "Zainichi" as Foundation, pp. 299-304. (Tokyo: Chikuma Shobo, 1995).

Wenders, Melissa L. Lamentation as History: Narratives by Koreans in Japan, 1965-2000. Stanford, Calif: Stanford University Press, 2005). 



\section{The Shaping of the Nation in Nanon and 93}

Alice AUDOIN

ccording to Richard Terdiman the $1789-1815$ revolutionary
rupture traumatized XIXth century French society, because it
dissociated the present from collective historical memory. In Terdiman's words, French people experienced a "'memory crisis': a sense that their past had somehow evaded memory, that recollection had ceased to integrate with consciousness. In this memory crisis the very coherence of time and of subjectivity seemed disarticulated" (3-4).

Indeed, the pre-revolutionary past, which French people of the nineteenth-century may have recalled, is no longer inscribed in historical continuity throughout the new century. The succession of various regimes illustrated the struggle of a people trying to make sense of the new historical dynamic arising after 1789. Eventually, we may affirm that there will be no going back to the past. On September 17, 1853, Edgar Quinet, after he finished reading the last volumes of La Révolution francaise by Michelet, wrote Michelet a letter in which he claims that "[v]ous avez tiré le rideau. Tout désir d'imitation devrait cesser pour jamais après ce récit, il faudra enfin que notre génération renonce à son existence d'emprunt. Vous lui fermez le retour vers ce passé ; il n'est plus possible ; après ce que vous dites" (Le Guillou 549).

For George Sand and Victor Hugo nonetheless, the relationship the French have with their revolutionary heritage is more complex. Nanon 
(published in 1872) and 93 (published in 1874), ponder the tensions existing in society in the nineteenth-century. On the one hand, one wants to side with Quinet and affirm that the revolution is past. On the other hand, how to deny that the events of 1830,1848 and 1871 were fathered by 1789 and 1793 ? The Revolution outlived its actors, who bequeathed to future generations a contentious political scene. My hypothesis is that nineteenth-century society developed in the stretching gap between republican ideals and their delayed realization. Quinet's affirmation is a wish that still had not been granted by the 1870 's. The Commune, therefore, was the product of historical tensions within the ambiguous past since the Revolution, and presented itself as the memory crisis' strongest symptom.

I now propose to show that Sand and Hugo made an attempt to reconcile society with itself after the Commune. To do so, they traced the origin of the rupture within society back to the Revolution, in order to understand the present and to prepare France for modernity. They retrospectively exemplified De Certeau's argument about history, 'la place qu'elle taille au passé est également une manière de faire place à un avenir' (Certeau 100). After assessing the state of France's historical memory in the postCommune era, Sand and Hugo advocated the construction of a better nation, through mythical sacrifices. Indeed, shaping the nation implied coming to terms with History by homogenizing collective memory. The idea was that all classes would be able to refer to the same History, while analyzing their past in order to understand their present. Their irreconcilable takes on what collective memory should be, however, made the task a complex one.

Throughout the nineteenth-century, the societal rupture, with its revolutionary origins, prevented the nation from fully forming. It was a repetition of this failure, which was acted out during the Commune. In her novel Nanon, Sand traces the origin of the 1871 political turmoil back to the Revolution. The life of the eponymous heroine Nanon is almost an allegory for nineteenth-century French history. Indeed, Nanon, who was a teenager in 1789 , decided to write her "mémoires" in 1850 , that is to say two years after the events of February and June 1848. The novel itself was published a year after the fall of the Commune. Through Nanon, who merges in perspective with George Sand, the nineteenth-century becomes aware of itself and of the strain tearing apart French society. Nanon, living during the Revolution, offers to the 1872 reader a vivid illustration of the revolutionary events that may have caused contemporary troubles. It is important to distinguish, in what I have been calling the Revolution, between two antithetical moments. If 1789 symbolizes reconciliation, 1793 incarnates rupture. 'Il faut nous débarrasser des theories de 93' wrote 
Sand, 'elles nous ont perdus. Terreur et Saint-Barthélémy, c'est la meme voie' (Politique I 275). Hugo would certainly agree with her, since the third book of his third chapter in 93 is entitled 'Le massacre de la SaintBarthélémy' (973). Whereas 1789 is the time of the 'Fête de la Fédération' and of reconciliation among the French people toward the shaping of a French nation, Hugo's 93 relates the Vendée wars that took place during the dramatic year of 1793 and emphasizes rupture as a fundamental aspect of the Revolution. The more heads fall, the more estranged to the Ancien régime French society becomes, or so thought the revolutionaries described by Hugo. Thus, of 'La Tourgue' - a feudal castle belonging to Gauvain and Lantenac's family - he wrote: 'Dans la Tourgue étaient condensés quinze cents ans [...]; dans la guillotine une année, 93; et ces douze mois faisaient contre-poids à ces quinze siècles' (1061). The two-act Revolution led to a new society in two periods. Before inaugurating modern history, it inscribed feudality within the realm of the past.

During the Revolution new relationships emerged within society. The revolutionary onslaught on Old Regime hierarchy brought forth changes for the aristocracy, as well as changes of relations between the 'orders' (clergy, nobles and third estate). Therefore, in Nanon, the second-born marquis is no longer pressured to remain in a convent, the Revolution having liberated him from primogeniture. As a consequence of the orders' overthrow, the Marquis de Franqueville may marry Nanon the peasant. Everyone, however, does not accept such changes and Emilien, the Marquis, declares that "l'alliance du noble et du paysan est plus facile que l'alliance de la bourgeoisie et de la noblesse. Ces deux classes se haissent trop" (226). This is why Nanon and Emilien share an idyllic love, while the bourgeois Costejoux and Louise, Emilien's sister, endure a strife-filled relationship. Sand here stresses two points: not only did the nobles never forgive the bourgeoisie for usurping their power; this rancor is still very much alive at the end of the nineteenth-century'. Along with a loss of political supremacy, the nobles have to accept that their memories of past grandeur have become hopelessly anachronistic:

Une intrigue annexe entre Costejoux et Louise, la soeur d'Emilien, permet à George Sand de développer une réflexion sur la séparation que représente encore la mémoire de la noblesse, séparation que le temps devra suturer. (Neefs 140)

What exactly does this memory consist of? In 93, Lantenac, who is imprisoned in the Tourgue, admonishes Gauvain and denounces the Revolution soon to deprive France of its aristocratic memory: 
Monsieur le vicomte, vous ne savez peut-être plus ce que c'est qu'un gentilhomme. Et bien, en voilà un, c'est moi. Regardez ça. C'est curieux : ça croit en Dieu, ça croit à la tradition, ça croit à la famille, ça croit à ses aïeux, ça croit à l'exemple de son père, à la fidélité, à la loyauté, au devoir envers son prince, au respect des vieilles lois, à la vertu, à la justice [...]. (1044)

Lantenac in 93 and Louise in Nanon are the most attached to the nobility's memory and traditions. After the end of the Terror, Louise leaves Costejoux. To Emilien, who asked where and with whom his sister had gone, Costejoux answered:

Avec sa vieille parente, Mme de Montifault, la Vendéenne, la chouanne irréconciliable! Chargée par vos parents de veiller sur Louise, mais empêchée longtemps par le louable devoir de fomenter et de continuer la guerre civile, elle a pu enfin sortir du repaire ; elle est venue hier soir chercher Louise, et Louise l'a suivie. -Sans résistance? -Et sans regret ! (228)

The brother, Emilien, however, did not remain attached to memory associated with his class. To the example of his father, who fled France and joined the other Emigrants, Emilien opposed his own will and determination: "je ne suis le fils de personne quand il s'agit de trahir la France" $(105){ }^{2}$ When a noble thinks about marrying outside her class, it is not only the class of the spouse that will determine if the alliance will survive. It is first and foremost the noble's memory of his own nobility. Emilien, having renounced the aristocracy's traditions, easily marries Nanon, but it is only once Louise has detached herself from the memory of nobility that she loses her prejudices toward other classes, and consents to marry Costejoux.

As described above, nobles share a collective memory, but this memory is closely connected to feudalism. Not only is there a set of rules to determine the nobles' behavior within their class; in addition, nobles could foist their will on the people. Originally, feudalism was a system in which the poor paid taxes to the rich, in exchange for physical and material protection in time of war. In the eighteenth-century, taxes were still due to the aristocracy, although the duty to fight did not exclusively devolve upon its members anymore. The authentic feudal link between vassal and overlord had been broken for a long time before the Revolution, and what the Revolution attempted to end is the corrupt and unequal version of feudalism. Many aristocrats, however, acted during the Revolution as if the ancient feudality were still governing society. Thus in Nanon, Emilien's father joined the Emigrants because he believed his sword had to 
defend the monarchy: "Fournissez à M. Emilien l'argent nécessaire pour sortir de France et venir me rejoinder à l'armée de Condé," writes M. de Franqueville to Prémel, one of his servants. His action is justified by the ancient rules governing feudalism. Like Lantenac, the Marquis believes in serving the Prince.

In 93, Lantenac also acts and talks as if the ancient mechanism of feudality was still operating:

Ah! Vous ne voulez plus avoir de nobles! Eh bien, vous n'en aurez plus. Faites-en votre deuil. [...] Vous n'aurez plus les chevaliers de Fontenoy qui saluaient avant de tuer [...] si Alaric II revient, il ne trouvera plus en face de lui Clovis; si Abdérame revient, il ne trouvera plus en face de lui Charles Martel ; si les Saxons reviennent, ils ne trouveront plus devant eux Pépin. (1046)

Lantenac even refers to early feudalism, and to the legends that formed the memory of the aristocracy. In 93, there is an allusion to what feudality used to be in the Middle Ages, through the name of the hero, Gauvain. The name "Gauvain" takes us back to Chretien de Troyes and the age of medieval chivalry. Indeed, Gauvain clings to honor, the knight's dearest virtue. "Vainqueur, il se croyait le droit d'épargner les vaincus" (949), and, if really he needs to condemn his enemy to death: "Moi, dit Gauvain, je suis pour la mort militaire" (950), which he opposes to revolutionary death by the guillotine. Gauvain never gives up on "honor," and while he is being tried, he defends himself with these words: "Je suis coupable. [...] Quand le coupable reconnait sa faute, il sauve la seule chose qui vaille la peine d'être sauvée, l'honneur" (1051). Since medieval times, feudalism declined, and reversed itself in 93, where aristocratic values are now cherished by those who defected from its rank ${ }^{3}$. Honor is on Gauvain's side, not on Lantenac's, who eventually admitted to his nephew: "Je ne vous cache pas que j'ai fait ce que $\mathrm{j}$ ' ai pu pour vous tuer. Tel que vous me voyez, j'ai trois fois, moi-même, en personne, pointé un canon sur vous. Procédé discourtois, je l'avoue" (1044). ${ }^{4}$

The transfer of the aristocratic value, "honor," from the marquis de Lantenac to the Vicomte Gauvain is significant, and brings us back to the Middle Ages and to the chevaliers de la table ronde, where Gauvain was King Arthur's nephew. In Hugo's 93 however, Lantenac is no King Arthur. The corrupted version of feudalism at the end of eighteenthcentury France bars any such analogy. Moreover, after January 21, 1793, the King was dead.

Although the king was beheaded, time has not yet come for "la république de l'idéal" (93 1056), an expression Gauvain coined. "La république 
de l'idéal" is where Gauvain and Nanon meet. In a 1871 letter addressed to Juliette Adam, Sand wrote that "la République de l'idéal est loin, loin dans l'avenir" (Politique I 262). The 1792 Republic failed, as did the Commune, which Sand qualified as a "crise de vomissements" (Politique I 261). It is the Commune, the historical experience of a failure in reconciling the French with themselves, which prompted Sand and Hugo to search for the origin of this failure. Both perceived it in the French Revolution, which embodied a better idea of the future through reconciliation in 1789 , and which betrayed it in 1793 because of corruption (in Nanon, the bad monk Pamphile becomes a revolutionary who kills in his own interest) and because of human weakness: good-hearted people like Gauvain are too soft, and loyal revolutionaries like Cimourdain choose death over survival in a Revolution who guillotines her own children.

The fall of reconciliation into rupture, between 1789 and 1793, accounts for a remark by Michelet stating that the 1789 Revolution was a rupture and a foundation too. "Il ne faut pas dire: la Révolution, mais la Fondation" (Cours au collège de France (CCF) $2: 10,19$ ). The concepts of religion, family and country are wholly experienced after the Revolution, and this is mostly because of 1789 , not 1793 . And I will add, too, since Michelet was a historian, that in his view: "la troisième chose qui nous est devenue possible par la Révolution, c'est l'histoire" (CCF 2: 691). In his 1865 book La Révolution, Edgar Quinet endorsed his former colleague's view. ${ }^{6}$ The founding of a nation is what makes its history possible. Thus the concept of modern history was born.

The tension between reconciliation and rupture left a scar in French consciousness, and this scar allowed modern French history to unfold. Sand and Hugo witnessed its beginnings. "En un sens," wrote Béatrice Didier, "tous les romans de George Sand sont 'historiques' dans la mesure où la présence de l'Histoire y est fortement sentie, fortement rappelée" (752). Nanon takes place from 1787 to 1850 , and even though no real historical character appears in the novel, events such as the Fête de la Fédération or the creation of the Comité de Salut public reproduce the historical setting of the revolutionary period. The real Vendée uprising that took place in 1793 and its leaders, such as Cathelineau and Bonchamp, constitute 93's historical background. The difference between Nanon and 93, as far as History is concerned, is that Marat, Danton and Robespierre not only are mentioned in 93 , but also actually engage in fictitious dialogue.

The advantage of a novel based on a historical background is of consequence. Sand and Hugo use History in order to demonstrate what the French Revolution implied for the nineteenth-century, and conversely, their 
ideas are justified by History itself. As Hugo wrote to Michelet in 1866, "[J]e ne suis rien que le témoin du dix-neuvième siècle' (Correspondance générale 10:67). He and Sand gave this century a subjective voice, which is not that of Marat, but that of a people talking behind Marat, or Nanon. Hugo and Sand's respective interpretations of revolutionary dialogue reveal their sense of History. The foundation of history started in a very tense society where feudality, a system that had regulated French society since the Middle Ages, was falling to pieces. Subsequently, new values emerged to replace the ones cherished by the Old Regime. During the Revolution, the French sought to revise the values attached to family, country and religion.

In his Cours au collège de France, Michelet advocated family and country as new values for the French people (2: 143). Family and country start with fraternity. "Il faut, pour que le monde nous vienne [...] qu'il nous voie un cœur fraternel. C'est la fraternité de l'amour qui le gagnera, et non celle de la guillotine" (Histoire de la Révolution française (HRF) 4). Externally, fraternity explains why the Revolution "avait convié le monde à l'amour et à la paix [...]" (HRF 2). Internally, it calls for stronger family values.

Nanon is predisposed to family values from the start. While she is crying over the death of her great-uncle, who raised her after the death of her parents, Emilien tells her, "[T]u as une grande force d'amitié; on ne te rendra pas cela comme tu le mérites" (62). Nanon's family during the Revolution is inexistent and broad at the same time. On the one hand it is inexistent because her great uncle was her last relative, but on the other hand it is large because once alone, Nanon idealistically treats everyone in her community as if they were kin to her. For Emilien as well as for her friend Costejoux, Nanon readily sacrifices herself. In Nanon the idea of "family" joins that of a "country" or even "nation." Without openly professing it, she adheres to Michelet's idea, that fraternity is necessary in the building of post-revolutionary French society. In contrast to Nanon, Louise remains cloistered within the Franqueville society, which to her represents family in terms of class. Through her last name, Louise seeks to reclaim her aristocratic origins. While she pines for the Old Regime, Nanon celebrates a new family, which embodies the ideal of republican fraternity.

In 93, family is represented by Michelle Fléchard and her children. This however, is more about maternity than about family, since it is the mother's frightening scream that saves her children in the end. Eventually, Sand and Hugo conceptualized the progression from "family by 
blood" to "the nation as a family." In this progression, Sand nonetheless saw one movement where Hugo distinguished two. If Sand thought that post-revolutionary society envisioned family values as progress towards fraternity within the nation, Hugo speculated that progress towards fraternity via family values first required a step back, towards nuclear family and maternal instinct. Michelle Fléchard and her children embody this first step. Secondly, it is only after maternity was affirmed as a basis for modern society, that Hugo in 93 integrated the idea of the nation as an enlarged family. This second moment is embodied by the adoption of Michelle Fléchard and her children by the Sergeant Radoub and the Bataillon du Bonnet Rouge: "Camarades, de tout ca je conclus que le bataillon va devenir père. Est-ce bien convenu? Nous adoptons ces trois enfants là. —Vive la République! Crièrent les grenadiers" (797). Therefore, while Nanon imbricates family values and post-revolutionary society, 93 advocates family "in a state of Nature," in which the single mother raises her children and obeys her instincts, which can be compared to those of a wolf: "La mère reconnut ses enfants. Elle jeta un cri effrayant. Ce cri de l'inexprimable angoisse n'est donné qu'aux mères [...]. Quand une femme le jette, on croit entendre une louve ; quand une louve le pousse, on croit entendre une femme" (1023).

The progression in Hugo from nuclear family to the nation-family requires the sacrifice of feudality: "abolir la féodalité, c'est fonder la famille" says Gauvain (1037). Gauvain's death reinforces the idea that though feudal values (and especially the honor that Gauvain embodies) may vanish, feudality as a system never will. In setting Lantenac loose, Gauvain accepts that the dominant class is stronger and should win, which violently contradicts the idea of a nation as an enlarged family, and restores the reign of Nature. Family relationships in 93 show that the Revolution will not change people's minds', because society holds on to its most traditional and natural values, even in the midst of violent upheaval. Gauvain, like Nanon's uncle, the père Jean, dies before any significant social change can occur. With Gauvain's death, Hugo stresses the Revolution's failure to penetrate the French mind.

Michelet wrote, "Il ne faut pas que la Révolution soit extérieure [...] il faut qu'elle entre et pénètre" ( $C C F$ 2: 393). ${ }^{7}$ Later Quinet subscribed to this view: "La révolution doit transformer l'homme en dedans. Sinon, elle n'est pas terminée" (144). The Revolution, however, tried to permeate French society through the concept of country, or nation. The Fête de la Fédération, on July 14, 1790, served this purpose.

In 1848, "le gouvernement provisoire a convié le peuple au Champ de Mars pour y célébrer la fete philosophique de l'oubli des haines et y 
bruler l'échafaud" (Blanc V). George Sand was there, on April 21, 1848 (Schor 135). This is, I am assuming, what prompted Sand to accord such importance to the Fête de la Fédération in Nanon, in 1850 and 1874. The 14 July 1790 Fête de la Fédération was the culminating point of reconciliation after 1789 , even though a difficult future loomed. Nanon observes after the Fête de la Fédération that "[t]out allait s'embrouiller et se gater" (74). Quinet wrote about the Fête's preparation: "Voilà le moment où les cœurs fraternisèrent véritablement. Le lendemain, 14 juillet, la fete parut froide et officielle [...] le faux entrait de toutes parts [...] les drapeaux [...] les acclamations couvrirent ces presages" $(231) .{ }^{8}$ The gesture nonetheless proves that the French honestly wanted a better nation.

The concept of nation is indistinguishable from that of country. In 1789 , parallel to the idea of a "nation" as an enlarged family, persists that of a nation as a group of people belonging to the same patrie. Before and during the Revolution, the patrie was nothing comparable to what it is today, with each province using its version of the French language, baking its own bread, or weaving its own garments. Patrie is the name of something yet inexistent, just as the pater, or biological "father," is absent from the family in Nanon and 93. The shaping of the French nation via complex family values and via patrie-building implies the restitution the pater figure.

During the Revolution, Paris and the Provinces did not experience the same events. Hugo in 93 separated the actions taking place in Vendée from the ones taking place in Paris. The first and third parts ('en mer' and 'en Vendée') are set in the West, whereas the middle part takes place in Paris and is called "A Paris." In 93 and in Nanon, set in Nohant, Paris is removed from the scene of events, although in both novels characters implicitly acknowledge that Paris is the "avant-garde" of the Revolution. Decisions and events taking place in the French capital are belatedly echoed in the Provinces.

La revolution était donc commencée et nous ne le savions pas. Pourtant le bruit de la prise de la Bastille se répandit un jour de marché, et comme cela causait quelque émotion dans la paroisse, je fus envieuse de savoir ce que cela pouvait être : la Bastille! (Nanon 49)

This delay between the time events took place, and the time peasants in Nohant became aware of them, changed the peasants' perception, compared to how Parisians could perceive the same event. Thus, although the fall of the Bastille was in Paris more important than the "grande peur" that followed it, Nohant's inhabitants took the opposite view: "Le souvenir. 
de cette panique est resté dans nos campagnes comme ce qui a le plus marqué pour nous dans la revolution. On l'appelle encore l'année de la grand-peur" (52). The fact that the Provinces were marked by the "grandpeur," which started through rumors, and less by the fall of the Bastille, reveals a gap between the educated Parisians and the illiterate peasants. Hugo, aware of this gap, weighed almost literally the Revolution and the peasant from the Province:

Si l'on veut comprendre la Vendée, qu'on se figure cet antagonisme: d'un coté la revolution francaise, de l'autre le paysan breton. En face de ces événements incomparables [...] qu'on place ce sauvage grave et singulier [...] vivant de lait et de chataignes $[. .$.$] ayant sur le dos une veste de cuir avec des$ arabesques de soie, inculte et brodé, tatouant ses habits comme ses ancetres les Celtes avaient tatoué leurs visages [...] parlant une langue morte [...] aimant ses rois, ses seigneurs, ses pretres, ses poux [...]. Et qu'on se demande si cet aveugle pouvait accepter cette clarté. (916)

The Revolution fought for the patrie, when peasants from Brittany fought for the local "pays." Later on Hugo very clearly explained what was "civil" in the war among the French, between the Vendée and the Revolution: "Pays, Patrie, ces deux mots résument toute la guerre de Vendée; querelle de l'idée locale contre l'idée universelle; paysans contre patriots" (925). ${ }^{9}$ Moreover, only the revolutionaries were able to conceptualize the patrie: "L'idée vivante de patrie n'existait que parmi les révolutionnaires. L'ancien régime ne voyant la France que dans le roi, livrait sans remord une patrie qu'il ne reconnaissait plus" (Quinet 407). Therefore forming a nation also requires the sacrifice of one's "pays." The local "pays" must disappear in order for the patrie to exist. This is what Nanon expresses at the end of Nanon: "Devant le grand dévouement de mon fiancé à la patrie, j'étais devenue moins paysanne, c'est-à-dire plus Française" (234). Nanon relinquished her local identification to a "pays" in order to shape her French identity and become part of the French nation. ${ }^{10}$

Very closely tied to the discussion of patrie and "pays" is that of religion. The Fête de la Fédération, along with being a first step toward nation building, inaugurated a series of fraternal 'fêtes' which all resembled each other. Thus, the Fete de la Federation in Nanon prefigures the religiously inflected Fête de la Raison.

Nanon, dressed as a kind of a Greek goddess on July 14, 1790, recalls the debate between traditional Catholicism and alternative deism. Despite 
her Greek outfit, Nanon is far from being a pagan and recites her prayers every night. The revolutionary characters in Nanon (Costejoux) and in 93 (Gauvain, Cimourdain) do not plea for the abolition of religion and, so, differ from actual revolutionary discourse. This we may perhaps attribute to historical distance; although Sand and Hugo set their novels during the Revolution, they wrote them in the early eighteen seventies.

Patrie and religion go together. "La patrie," wrote Michelet about education, "doit aider à ce mouvement vers le haut. Elle doit avoir un role de prévoyance maternelle" (CCF 2: 30). The patrie performs the roles of father, mother, and Providence : "Enseignez d'abord [...] la patrie, comme Verbe de Dieu" (CCF 2: 93). Michelet and Quinet disagreed about what place Christianity played after the Revolution. For Michelet, the Revolution opened society to the possibility of a new religion, because in the Revolution itself he saw a new Church. He wrote in the 1868 preface to the Histoire de la révolution française: "Elle [la Révolution] n'adopta aucune Eglise. Pourquoi ? C'est qu'elle était une Eglise elle- meme" (HRF 12). For Quinet, however, the Revolution did more for Christianity than for the nation:

Le sang des Cathelineau [...] les paysans de Vendée ont obtenu ce qui leur mit les armes à la main. Ils ont gagné pour leur postérité la suprématie, en fait, de leur religion, la domination réelle de leurs prêtres, de leurs autels; ils les ont rétablis, non seulement pour eux, mais pour toute la France. Au contraire, la religion de liberté de leurs adversaires [...] Elle a disparu des âmes plus encore que des choses. (412)

This suggests that in 93, the victory of Lantenac is really that of Catholicism, especially in 1874. Indeed, the Vendée lost, but not Catholicism, celebrated in Le génie du christianisme no later than ten years after the fall of Louis XVI. Hugo shed light on the major fact that rather than abolish Catholicism, the Revolution made it appear in a state of crisis, from which issued its regeneration.

On a milder note, Sand did not portray Catholicism in a state of crisis. To her, the Revolution actually improved relations between the Clergy and the people. Nanon after all, persuades to the Père Fructueux, the new head monk in the Moutiers, to become "assermenté," or to swear to be loyal to the new Constitution. Therefore, the new Church of the Revolution results from the convergence of Catholicism and the Enlightenment.

As with family and the patrie, the celebration of religion requires a sacrifice. The eponymous heroine of Nanon offers herself as a sacrifice to 
the better times to come. She jeopardizes her own life for that of Emilien, sacrifices her beloved lamb Rosette for the well-being of Louise, and on the whole acts by gestures of abnegation, which eventually are rewarded. In 93, religion exacts a heavier toll: with his death, Gauvain expiates the crimes of Lantenac. It is afterwards an absolved Lantenac who departs from the Tourgue, not only to carry on the war against the Revolution, but also to defend the Vendée and uphold its Catholic traditions.

In the early Third Republic, Sand and Hugo managed to synthesize what the French ideologically inherited from the Revolution. After the fall of the Commune, time had come for the French to ponder how, practically, to assimilate this heritage - or, as Hugo put it, how to begin the "révolution humaine." For Sand's funeral, he wrote, "Dans ce siècle qui a pour loi d'achever la Révolution française et de commencer la révolution humaine [...]. Je pleure une morte et je salue une immortelle" (Bahiaoui 9-10). The human revolution, however, is just a part of a bigger scheme. It is time to prompt French society towards scientific and capitalist modernity in spite of itself. After the Franco-Prussian war, France understood it was being forced into modernity. Accentuating factors of reconciliation internal to society, such as family, patrie, and religion, was part of a double movement: moving backwards toward the Revolution, in order for the nation to assimilate it and understand its sacrifices at the time and entering modernity with more strength and unity. In Nanon and in 93 there is hope that the Commune was the last repetition of the sacrificial rituals necessary to shape the French nation. "Quant à la Commune, qui est en train de raler, c'est la dernière manifestation du Moyen-Age," wrote Flaubert to Sand in April 1871. "La dernière? Espérons-le !" (Correspondance Sand-Flaubert 332). The beheading of Gauvain in 93 also marks the burial of the Arthurian patronym. In Nanon, the link between the Revolution and the MiddleAges is broken through Emilien and Louise's loss of aristocratic memory.

Sand hoped to witness, in the post-Commune era, a resurgence of that sense of nationhood, whose promise had flickered briefly on July 14 , 1790. The reconciliation that followed the Commune retrospectively ended and sealed the Revolution's aborted attempt to constitute a nation and a "patrie." For Sand, family sustains the patrie's "epanouissement," for in defying the traditional conception of the nuclear family, she promotes a family as large as the nation. She is therefore close to Michelet, who in 1850 declared, "Notre foyer éphémère participe pourtant à l'éternité du foyer de la patrie" (CCF 2: 623).

Like family and the patrie, religion is in Sand's view a unifying and a strengthening force. She nonetheless departed from traditional Christian- 
ity, advocating instead an enlightened religion which still bore traces of the Revolution. "Que doit faire l'homme," wrote Michelet, "Une chose qui en comprend trois : famille, religion, patrie" (CCF 2 : 580). Nanon learned the new religion through her numerous sacrifices, and we can affirm more generally that the sacrifices required by the Revolution helped shape a certain idea of God. "J'ai enseigné que la Révolution n'était rien," wrote again Michelet, "si elle ne prenait racine dans le sacrifice et que le sacrifice n'était ni facile ni général autrement que par la foi et par la pensée de Dieu" (CCF 2: 645-646). In 1850, it is Nanon, Michelet's fictitious contemporary, who seems to agree with the historian. Sand used Nanon to reinforce Michelet's mid nineteenth-century historical discourse on the Revolution. She thus preserved, in the on-going project of nationhood, the nexus of society and religion.

On the other hand, Lantenac is antithetical to Nanon. Hugo's opinion of the Revolution and its legacy tends to contradict Sand's optimism. Where Sand observed progress and reconciliation, Hugo saw regression towards the Old Regime value system. Nanon could save Louise from the guillotine in spite of the aristocrat's opposition to the Revolution because in Nanon the enlarged family trumps violence and rupture. In 93, however, Gauvain signs his own death warrant in forgiving his Vendean uncle. In setting Lantenac free, Gauvain subsequently adheres to his uncle's aristocratic notions attached to family. In the aristocratic family, the father does not establish harmony, but embodies authority. To the enlarged nation-family, Lantenac opposes an enlarged conception of the father, who is not so much a biological father, as a chief. The Marquis decides after all, whether or not the Fléchard children will live; he does not eventually save them out of pure altruism - after all, it was he who locked them in La Tourgue in the first place - but to assert his absolute commanding position. Had the mother tried to jeopardize his authority and argued with him, he would probably not have saved the children. The wolf-like scream, however, propels the Marquis back inside La Tourgue to rescue the children from the flames. To Sand's utopia, Hugo opposes a world still based on instinctive patriarchal authority. In 93 the nation's values are subsumed under that of the Vendée, whose traditions and religion resurface strengthened. The "pays" and its Catholic traditions are eventually victorious, thus proving Quinet right.

Whereas Sand confirms Michelet's thesis and advocates enlarged family as the basis of the new nation, Hugo, through Lantenac, uses Quinet's conclusion in order to profess religion as the nation's cornerstone. Each opposes the other, as idealism opposes fatalistic realism; but if until 
the early twentieth-century religion remained important to French society, social reforms, responding to the idea of enlarged family, kept developing throughout the third Republic and the twentieth-century. Sand and Hugo initiated progress towards reconciliation, which eventually developed through the patrie's institutions.

\section{Notes}

1. Moreover, the Terror was led by the bourgeoisie, as the involvement of Costejoux in the Revolution illustrates. Michelet wrote: "les meneurs, nos grands Terroristes, n'étaient nullement des hommes du peuple, mais des bourgeois, des nobles, des esprits cultivés, subtils, bizarres, des sophistes et des scolastiques. » Le peuple (Paris : Flammarion, 1974) 135.

2. With this act, "le personage d'Emilien représente en actes la rupture avec l'ancien monde, en déclarant la rupture avec sa famille". Jaques Neefs, "Nanon, une fable de la mémoire historique." In George Sand: Littérature et politique (Nantes : Pleins feux, 2007) 139.

3. Emilien, defecting its rank by deciding to not join his father in Gernany, recalls the notion of honor too, when revolutionary war is mentioned : « Je suis né doux et je n'ai pas le gout de tuer des hommes ; mais il y aura peut-etre une question d'honneur et tu ne voudrais pas me voir méprisé ? » Nanon 94.

4. "Subitement, un éclair jaillit [...] et un boulet vint trouer une maison au-dessus de la tête de Gauvain. [...] Un second boulet suivit le premier et vint s'enfoncer dans le mut tout près de Gauvain. Un troisième boulet jeta à terre son chapeau. [...] Quelqu'un en effet visait Gauvain, c'était Lantenac. » (937-938)

5. "On oubliera pas, en premier lieu, que les écrivains contemporains, si l'on met à part Victor Hugo nuancé, Rimbaud et Verlaine qui n'ont rien écrit de très substantiel sur le sujet, Jules Vallès qui, lui, prit une part directe à l'événement, ont à peu près tous été violemment hostiles au mouvement parisien. La Commune a généralement été ressentie comme une apocalypse sociale, expression en pleine civilisation des pulsions les plus primitives et les plus bestiales de l'homme. » Littérature et histoire, George Sand: histoire et terroir (Rennes : Presses Universitaires de Rennes, 2006) 267. It is interesting to notice that bestiality, appearing in Michelle Fléchard's scream in 93, is what propulsed the last events of the novel, that is to say Lantenac's arrestation and Gauvain's beheading.

6. « Dans la France de l'ancien régime, écrire l'histoire de France était impossible. Cette histoire, avant la Révolution, n'avait été traitée 
par aucun grand esprit. Apparemment, le récit de cette longue servitude semblait intolérable ou indigne d'intérêt. [...] Il en fut autrement lorsque la liberté eut commencé à paraître. 》 La Révolution 67.

7. and later, in a letter to Quinet « Vous l'avez dit, c'est dans les esprits mêmes qu'il faut faire la révolution. Mais en meme temps, elle se fera profonde dans les choses. » 25 sept.53. In Correspondance générale de Michelet vol. 7, 561.

8. Mme de Stael herself wrote "Les spectateurs étoient dans l'ivresse ; le roi et la liberté leur paroissoient alors complètement réunis [...] Toutefois les personnes capables de réflexion étoient loin de se livrer à la joie générale » Considérations sur la Révolution francaise, ed. Jacques Godechot (1818; Paris : Tallandier, 1881, 1983) 227.

9. The dialogue between Radoub and Michelle Fléchard in the beginning of the novel also established a distinction between « pays » and «patrie »: «Quelle est ta patrie ? -Je ne sais pas, dit-elle. -Comment, tu ne sais pas quell est ton pays? -Ah! mon pays, si fait. » (792)

10. See also George Sand, Terroir et histoire.

\section{Works Cited}

Bahiaoui, Danielle. Correspondance croisée: George Sand Victor Hugo. Nïmes : HB, 2004.

Blanc, Louis. Histoire de la révolution de 1848. Paris: A. Lacroix, Verboeckhoven et ce, 1870.

Certeau, Michel de. L'écriture de l'histoire. Paris : Gallimard, 1975.

Didier, Béatrice. George Sand écrivain : un grand fleuve d'Amérique».

Paris: Presses universitaires de France, 1998.

Flaubert, Gustave, George Sand, éd Alphonse Jacobs. Correspondance.

Paris: Flammarion, 1981.

Hugo, Victor, éd Jacques Seebacher. Oeuvres complètes. Paris: R. Laffont, 1985.

Le Guillou, Louis, ed. Correspondance générale de Michelet. Vol. 7. Paris : Honoré Champion, 2000

Michelet, Jules. Cours au Collège de France, 1838-1851. Paris: Gallimard, 1995.

. Correspondance générale. Paris: Librairie Honoré Champion, 1994. - Le peuple. Ed. Paul Viallaneix. Paris: Flammarion, 1974.

- Histoire de la Révolution française. Ed. Gérard Walter. Paris: Gallimard, 1961. 
Neefs, Jacques. « Nanon, une fable de la mémoire historique » éd. Martine Reid et Michèle Riot-Sarcey. George Sand :littérature et politique. Nantes: Pleins feux, 2007.

Quinet, Edgar. La Révolution. Paris: Belin, 1987.

Sand, George, éd Huguette Bouchardeau. Politique. Nîmes: HB éditions, 2004.

Sand, George, éd Nicole Mozet. Nanon. Meylan France: Editions de l'Aurore, 1987.

Schor, Naomi. George Sand and Idealism. New York: Columbia University Press, 1993.

Staël, Mme de. Considérations sur la Révolution française. Ed. Jacques Léon Godechot. Paris: Tallandier, 1983.

Terdiman, Richard. Present Past: Modernity and the Memory Crisis. Ithaca, N.Y.: Cornell University Press, 1993.

"Littérature et histoire." George Sand, terroir et histoire. Dir.Noëlle

Dauphin. Rennes: Presses universitaires de Rennes, 2006. 


\section{Understanding Marcel Proust's Law of Desire}

Brody SMITH

Il n'y a que le désir et du social et rien d'autre.'

lthough best known as the magician of involuntary memory, Marcel Proust (1871-1922) also boasts a significant critical and 1 literary contribution to the development of queer theory and scholarship in the epic, A la recherche du temps perdu. The third volume, Sodome et Gomorrhe, directly and at length explores for the first time in the Proustian opus the theme of male homosexual relations. The comedy of the overture introduces the concept of "la race des tantes," loosely translated as the "race of queens." Oddly enough, the genesis of this work began with the treatment of the abject homosexual in one of Proust's earlier works included in the collection of essays Contre Saint-Beuve. This ground-breaking excerpt bears the title of "La race maudite," in translation the "accursed race" and provides the genesis for "la race des tantes." The fusion of the two works reveals Proust's literary transformation of the abject and marginalized homosexual into an integrated member of Parisian bourgeois society at the end of the nineteenth century.

What exactly defines abjection and its relevance to this essay? According to Julia Kristeva, the economics of abjection invariably force an existence outside of oneself: "Inlassablement, comme un bommerang indomptable, un pôle d'appel et de répulsion met celui qui en est habité littéralement hors de lui." 2 Using the comparison of an inescapable 
boomerang, Kristeva portrays the subject unable to avoid the incessant torments of abjection that result in psychic instability and identification. Concordantly, Judith Butler defines and explicates related spatial complexities of abjection:

This exclusionary matrix by which subjects are formed thus requires the simultaneous production of a domain of abject beings...The abject designates here precisely those "unlivable" and "uninhabitable" zones of social life which are nevertheless densely populated by those who do not enjoy the status of subject, but whose living under the sign of the "unlivable" is required to circumscribe the domain of the subject. This zone of uninhabitability will constitute the defining limit of the subject's domain; it will constitute the site of the dreaded identification against which - and by virtue of which - the domain of the subject will circumscribe its own claim to autonomy and life. In this sense, then, the subject is constituted through the force of exclusion and abjection, one which produces a constitutive outside to the subject, an abjected outside, which is, after all, "inside" the subject as its own founding repudiation. ${ }^{3}$

By way of detailed explication, Butler interprets the complex zones marked by the abject subject's constitution. In concert, Kristeva and Butler set forth the interior and exterior quality and attributes of abjection, thereby pointing to a bifurcated existence. These dimensions provide indispensable frames of reference in order to better understand the stakes for the queer subject.

Although Proust's two literary works share a common homosexual subject, contradictions endure. For example, "La race maudite" depicts the solitary provincial life of the melancholic homosexual. On the other hand, the overture to Sodome et Gomorrhe recounts the comical observation of two Parisian men from different social classes, who, nonetheless, find a way to hook up. Abjection thus undergoes a metamorphosis. Repression yields to a world where alternative expressions of sexuality are governed by sheer desire. In other words, Proust's Utopia transcends any theory of uninhabitable zones and self-repudiation. Nor do social constructs limit access to sexual pleasure.

"La race maudite" prepares the reader for Sodom and Gomorrah. The Parisian aristocracy provides the backdrop for the encounter with the abject homosexual: the Marquis de Quercy. The narrator receives an invitation to the afternoon salon of the Prince and Princesse de Guermantes, who happen to be relatives of his neighbors, as well as relatives of the Marquis. Since the narrator belongs to the bourgeois class, Proust sets in motion 
an initial inversion of bourgeois versus aristocracy in order to illustrate tensions between the social classes of his time. Although the narrator frequents the local nobility, he still maintains his bourgeois status.

Prior to their meeting in the salon, the narrator has already noticed various details of the Marquis' routine through a voyeuristic gaze. From the vantage point of the window of his own apartment, he has seen the Marquis come and go from the Guermantes' residence. During the salon, the narrator introduces himself to the Marquis in a somewhat awkward fashion, yet no evident contact occurs. Nonetheless, the narrator knows he has been seen; thus, the gaze reverses. Subsequently, the Marquis retires, and the narrator begins a detailed account that will lead to a surprising discovery:

Pauvre M. de Quercy, qui aime tant la virilité, s'il savait l'air que je trouve à l'être las et souriant que j'ai devant moi. On dirait que c'est une femme! J'avais compris, c'en était une! C'en était une. ${ }^{4}$ Although the narrator names what he sees, these impressions create suspicions in the reader's mind as to the sexual orientation and gender of the Marquis, especially given the use of the feminine indefinite article "une." By actually articulating the description, the narrator confirms the definition. From his perspective, a homosexual is a woman, or better yet, a woman trapped in a man's body, thus complicating the assignment of any conventional gender marker.

At this point begins the description of the abject homosexual and his depraved lifestyle. Proust pens a famous sentence that extends over four pages. Therein, the rhetorical device of accumulation serves to bundle together ignominious traits and habits. The beginning of this section harkens back to the title of Proust's essay:

Race maudite puisque ce qui est pour elle l'idéal de la beauté et l'aliment du désir est aussi l'objet de la honte et la peur du châtiment, et qu'elle est obligée de vivre jusque sur les bancs du tribunal où elle vient comme accusée et devant le Christ. ${ }^{5}$

Through multiple binary oppositions, this passage portrays the existence of the homosexual as a complete lie. His desires do not align with acceptable social norms. Consequently, the homosexual is obliged to live on the margins, underscoring Butler's idea of zones of existence. In this case, the reprobate occupies a bench awaiting the judgment of Christ.

Furthermore, Proust substitutes conventional gendered pronouns with the neutral "it," thereby referring to a race or collective "it." To further. complicate matters, in French, the pronoun "elle" replaces la race. Thus, on numerous levels, language forces the lines of gender to be blurred. 
Traditional paradigms do not seem to function appropriately in this dimension. Yet Proust insists on ambiguity for a reason. The climax of the description of the abject character of the homosexual occurs toward the end of this section:

Car ses crimes peuvent être momentanés et chacun peut comprendre l'acte d'un voleur, d'un assassin mais non d'un homosexuel; partie donc réprouvée de l'humanité, mais membre pourtant essentiel, invisible, innombrable de la famille humaine." According to this passage, homosexuality defies comprehension and exceeds the potential consequences and punishments of theft and murder. Proust continues to emphasize the depiction of a hateful and outcast group. Anxiety enters the dynamic when conventional boundaries are crossed, thereby confusing social constructs and destabilizing traditional points of demarcation. Proust has already raised the level of ambiguity by referring to the Marquis de Quercy as a woman and a member of another race. However, the last words of the citation contradict previous denouncements. In spite of all their undesirable qualities, homosexuals remain essential members of the human race, invisible and too many to count.

Proust continues to manipulate conventional borders of gender and sexuality as he reflects on the challenge of fulfillment of homosexual desire:

Mais le plus souvent se contentant d'apparences grossières, et faute de trouver non pas l'homme-femme, mais la femme-homme qu'il leur faut, ils achètent d'un homme des faveurs de femme, ou par illusion dont le plaisir finit par embellir ceux qui le procurent, trouvent quelque charme viril aux êtres tout efféminés qui les aiment. ${ }^{\text {? }}$

In other words, the homosexual must be satisfied by exaggeration and never achieve what he ultimately desires. The fantasy or the mirage of the homosexual denotes a longing for sexual union with the masculine. Proust posits that a masculine woman fails to satisfy, while the effeminate man only serves as a surrogate. The physical attributes of an effeminate man allow the homosexual to play out the fantasy of a sexual encounter or relationship with the masculine during the ephemeral literal and figurative jouissance.

The end of the essay returns to the specific plight of the provincial life of the Marquis de Quercy. The reader learns that the Marquis had adolescent homosexual relations with his cousin who later marries. Now twenty-five years old, the Marquis relocates to Paris. The narrator describes him as an "Andromède attachée à un sexe pour lequel il n'était point 
fait." Succinctly put, male genitalia prevent true sexual orientation and encumber its expression. The Marquis appears to resign himself to these limitations through marriage to a woman:

Il s'éprit d'une fille de haute naissance qu'il épousa et pendant quinze ans ses désirs furent tous contenus dans le désir d'elle, comme une eau profonde dans une piscine azurée.

In order to function in his cultural and social location, the Marquis transfers his latent desires for another man by marrying a woman of his own social status. For fifteen years, his true desires were contained in his desire for his wife. The binary of the river and the pool suggests the convergence of two different bodies, a metaphor for the exceedingly difficult task of managing such a complicated identity. Once again, we find ourselves in a different zone of existence. The narrator further relates that the Marquis reverts to his former sexual proclivities, "mais sa situation le préservait un peu." 10 The Marquis' social standing provides little advantage and does not completely protect him. This comment further illustrates the erasure of conventional class boundaries.

On the other hand, in Sodome et Gomorrhe, auto-homophobia undergoes a transformation. Proust therein creates a world which valorizes the acceptance and social integration of the homosexual. The overture begins with an epigraph taken from the poem "La colère de Samson" by Alfred de Vigny: "La femme aura Gomorrhe et l'homme aura Sodome." " Proust thus appropriates the theme of homosexuality from another published literary work in order to introduce his own agenda. Alfred de Vigny projects his personal anxiety over suspicions that his current female companion may have a secret sexual alliance with another woman. He denounces this relationship in the quotation. In effect, Proust introduces the topic indirectly through resistance and containment: A taboo issue surfaces but, at the same time, is managed so as not to go too far. For the time being, the homosexual is metaphorically contained in an abject biblical and historical space.

In Sodome et Gomorrhe, the hesitancy of Proust to take on this forbidden subject parallels that of the narrator. The Marquis de Quercy from "La race des tantes" undergoes a metamorphosis and becomes the Baron de Charlus. In the opening paragraph, the reader is prepared for what is to come:

[...] j'avais épié leur retour et fait, pendant la durée de mon guet, une découverte, concernant particulièrement $M$. de Charlus, mais si importante en elle-même que j'ai jusqu'ici, jusqu'au moment de pouvoir lui donner la place et l'étendue voulues, différé de la rapporter. ${ }^{12}$ 
Proust, the voyeur, engages us yet again. "It" does not presently have a name. In the Proustian sphere, the exposition of the subject of homosexuality requires adequate preparation, including procrastination and avoidance. The text arrives at an important revelation. As in the beginning of " $\mathrm{La}$ race maudite," the narrator observes without being seen. He witnesses the unplanned initial encounter of the Baron de Charlus with the family waistcoat maker, Jupien. Harkening back to "La race maudite," the narrator reacts to Charlus' appearance: "...c'était à une femme!"13 However, this description does not seem to conflict with Jupien's preferences:

M. de Charlus... avait recontré le giletier et avec lui la bonne fortune reservée aux hommes du genre du baron par un de ces êtres qui peuvent même être, on le verra, infiniment plus jeunes que Jupien et plus beaux, l'homme predestiné pour que ceux-ci aient leur part de volupté sur cette terre: l'homme qui n'aime que les vieux messieurs. ${ }^{14}$

This reference signals a rejection of abjection. Aristocracy now mingles with a family retainer. The opportunity of homosexual relations outside the extended family and social class breaks through and transgresses conventions but is again contained through secret trysts. There is even a particular subgroup of younger homosexual men that desire older men. Proust expands the homosexual community and allows it to blur another aspect of the social order in yet another inversion: elderly and youthful.

In fact, the narrator actually hears the sexual encounter between the two men:

Car d'après ce que j'entendis les premiers temps dans celle de Jupien et qui ne furent que des sons inarticulés, je suppose que peu de paroles furent prononcées. Il est vrai que ces sons étaient si violents que, s'il n'avaient pas été toujours repris un octave plus haut que par une plainte parallèle, j'aurais pu croire qu'une personne en égorgeait une autre à côté de moi et qu'ensuite le meurtrier et sa victime ressuscitée prenaient un bain pour effacer les traces du crime. J'en conclus plus tard qu'il y a une chose aussi bruyante que la souffrance, c'est le plaisir, surtout quand s'y ajoutent des soucis immédiats de propreté. ${ }^{\text {s }}$

This scene between Jupien and Charlus illustrates the daring nature of the narrative. The narrator experiences the encounter through a multiplicity of violent sounds of torture and pain without dialogue. Consequently, he draws a parallel between levels of loudness in both cries of suffering and pleasure. Of particular interest is the issue of cleanliness. This reference underscores both the shame associated with the sexual act and the neces- 
sary disposal of any physical evidence. Michel Foucault's commentary on historical sexual discourse resonates with the text:

Mais, au-delà de ces plaisirs troubles, elle revendiquait d'autres pouvoirs; elle se posait en instance souveraine des impératifs d'hygiène, ramassant les vieilles peurs du mal vénérien avec les themes nouveaux de l'asepsie... elle prétendait assurer la vigueur physique et la propreté morale du corps social. ${ }^{16}$

Concerning hygiene, Foucault relates the ever-present longstanding fears of venereal disease along with the new issues concerning asepsis. He also circumscribes the need to ensure physical vigor and the moral propriety of society through cleanliness. Charlus and Jupien take Foucault a step further. They must safeguard their secret. To that end, a bath proves necessary.

Without doubt, Proust remained exceedingly concerned about the public's reaction to this text. In his biography of Marcel Proust, William C. Carter asserts: "Proust wanted to prepare readers and critics for the opening pages of Sodome et Gomorrhe."17 He even requested the critical opinion of the French novelist, François Mauriac, a devout Catholic. Mauriac's response proves evasive at best: "The examination of one's conscience is the basis of all moral life, and Proust projects a terrible light on our inner depths."18 Whether or not he intended to do so, Mauriac infers that a closeted homosexual lives inside every person. Perhaps he did not fully comprehend the text. Clearly, Proust becomes the architect of a new literary space which threatens conventional understandings of gender and sexuality, for earlier Honoré de Balzac could only hint at Vautrin's desire for Lucien de Rubempré at the very end of Les Illusions perdues and throughout Splendeurs et misères des courtisanes.

The author continues to reappropriate the abject experiences of the Marquis de Quercy by describing the hook up of two men of different classes and age groups. Comedy enters the dialogue with the description of the courtship between Jupien and the Baron de Charlus:

Or Jupien, perdant aussitôt l'air humble et bon que j'avais toujours connu, avait - en symétrie parfaite avec le baron redressé la tête, donnait à sa taille un port avantageux, posait avec une impertinence grotesque son poing sur la hanche, faisait saillir son derrière...Je ne savais pas qu'il pût avoir l'air si antipathique. ${ }^{19}$

Similar to a species of exotic birds, Jupien and the Baron perform an exaggerated seduction dance that will lead to their conjunction. Jupien, the principal actor, throws his head back, puts his wrist on his hip and sticks out his behind. Proust accents the hilarity with the following comment 
regarding this spectacle, which he likens to a theatrical performance: "Cette scène n'était, du reste, pas positivement comique." ${ }^{20}$ Through the use of the rhetorical device of negation the reader understands how truly comical the antics appear. After their tryst, and during the course of a volley of sarcastic exchanges, Jupien informs the Baron de Charlus: "Vous en avez un gros petard!"21 Why is this particular exclamation funny? Walter Benjamin provides a response by defining the quality of Proustian comedy in $A$ la recherche du temps perdu:

In the treasury of its prejudices and maxims there is not one that is not annihilated by a dangerous comic element... His style is comedy, not humor, his laughter does not toss the world up but flings it down - at the risk that it will be smashed to pieces... And unity of family and personality, of sexual morality and professional honor, are indeed smashed to bits. The pretensions of the bourgeoisie are shattered by laughter. Their return and reassimilation by the aristocracy is the sociological theme of the work. ${ }^{22}$

Benjamin accurately describes the Jupien/Charlus encounter. The potential scandal of social transgressions cannot escape Proust's wit. Through his daring, he literally shatters conventions and norms. Benjamin further states: "The reader of Proust is constantly jarred by small shocks." ${ }^{23}$ Levity thus opens the mind of the reader concerning the behavior of homosexuals and their pervasive existence in society - a wonderful example of comic relief.

Proust, master of French syntax, again composes a string of modifiers that continue over the space of approximately four pages of the text. Yet here the tone differs. Homosexuals still constitute a race apart, but they are no longer regarded as thieves and murderers. The form a secret association that Proust likens to freemasons, except that homosexuals are more efficient and less suspect than ordinary lodge members:

[...] car elle repose sur une identité de goûts, de besoins, d'habitudes, de dangers, d'apprentissage, de savoir, de trafic, de glossaire, et dans laquelle les membres souhaitent de ne pas se connaître, aussitôt se reconnaissent à des signes naturels ou de convention, involontaires ou voulus. ${ }^{24}$

In this passage, the narrator compiles a list of attributes that bring this group together, consisting in an identity that functions on a variety of levels, not all of which are determined by the individual. While they may have common interests and tastes, they also come together in danger situations, the newcomers learning the trade - literally and figuratively - from the 
more experienced, thus assuring the continuation of the species. They share a special lexicon that allows them to communicate without being understood by the uninitiated. However, we return to the theme of selfrepudiation of "La race des tantes" when the narrator states that irrespective of common ground, they do not want to know one another. Nonetheless, recognition comes through means that cannot be controlled or measured. Their identity reflects self-loathing and repulsion. Paradoxically, these aversions also extend to members of their confrérie.

Arguing from a historical perspective, Michel Foucault states that a homosexual identity and subculture were invented at the end of the nineteenth century:

Il ne faut pas oublier que la catégorie psychologique, psychiatrique, médicale de l'homosexualité s'est constituée un jour où on l'a caractérisée - le fameux article de Westphal en 1870 , sur les "sensations sexuelles contraires" peut valoir comme date de naissance - moins par un type de relations sexuelles, une certaine manière d'intervenir en soi-même le masculin et le féminin. L'homosexualité est apparue comme une des figures de la sexualité lorsqu'elle a été rabattue de la pratique de la sodomie sur une sorte d'androgynie intérieure, un hermaphrodisme de l'âme. Le sodomite était un relaps, l'homosexuel est maintenant une espèce. ${ }^{25}$

Foucault defines homosexuality not initially based on sexual relations but rather as the individual's interior sorting out of male and female identities, such as hermaphrodism. Furthermore, homosexuality acquired its sexual connotations with the advent of sodomy identified with internal gender associations, or the lack thereof. In other words, the economics of sexual desire can resist containment only to a certain point. Homosexuals henceforth constitute a species, a circumscription that resonates with Proust's race maudite.

At the end of the thirty-two page overture, the narrator now expands the homosexual community to a global status:

Certes il forment dans tous les pays une colonie orientale, cultivée, musicienne, médisante, qui a des qualités charmantes et d'insupportable défauts. On les verra d'une façon plus approfondie au cours des pages qui suivront; mais on a voulu provisoirement prévenir l'erreur funeste qui consisterait, de même qu'on a encouragé à créer un mouvement sodomiste et à rebâtir Sodome. ${ }^{26}$ To begin with, the narrator continues to portray paradox between the erudition and the sarcasm of the homosexual. By way of this provocative 
and sardonic statement, Proust in his own manner allows the homosexual subject to enter the public domain again through resistance and containment: They are charming but mean and are found everywhere. Textually, he purposely delays revealing too much too soon, so as not to provoke the reaction that he may be encouraging a membership drive of sorts, literally calling for the formation of a movement of Sodomists with the intention of rebuilding Sodom. This negative depiction continues to draw criticism. For example, André Gide publicly denounced Proust's attempt to render the material elusive. More recently, in Homos, Leo Bersani attempts to reduce the depiction of the Proustian gay community to a bitchy and essentially heterosexual text, without fully understanding the complicated nuances and historicity of Proust's homosexual subject. Another odd treatment can be found in Joseph Litvak's Strange Gourmets, where the author tries to build a case for the primacy of the homosexual's intelligence and arrogance. While these traits certainly exist, such a monochromatic approach belies the overarching complexity of Proust's evolutionary text.

Similar nuances, related to the destabilization of conventional gender markers, are addressed in a more sophisticated manner in the next sequence. In "La race maudite," the narrator proposes the idea of the homosexual as a woman trapped inside the body of a man. Proust now further develops this image by describing an effeminate young man waking up in bed:

Quelques-uns, si on les surprend le matin, encore couchés, montrent une admirable tête de femme, tant l'expression est générale et symbolise tout le sexe; les cheveux eux-mêmes l'affirment; leur inflexion est si féminine, déroulés, ils tombent si naturellement en tresses sur la joue, qu'on s'émerveille que la jeune femme, la jeune fille, Galatée qui s'éveille à peine dans l'inconscient de ce corps d'homme où elle est enfermée. ${ }^{27}$

Initially, the text points to the element of surprise required of the voyeuristic gaze in order to witness this seemingly natural phenomenon. We then continue with the identifying elements of face and hair, which, according to the narrator, symbolize the female sex in its entirety. In particular, the movement of the hair frames the face in a manner to render it feminine, causing the onlooker to marvel at the awakening of the unconscious Galatea held captive in a man's body. The central idea of this passage finds a parallel in the novel Monsieur Vénus by the French author Rachilde. Written in 1883, Monsieur Vénus tackles the reversal of conventional sexual roles. Rachilde employs the template of the woman-man and the man-woman to confuse conventional ideas of gender. Evidently, the liter- 
ary preoccupation concerning a way to transcend traditional sexual markers predates Proust. At the same time, the wealth of scholarship dedicated to gender studies and sexuality underscores the fact that we continue to seek to deconstruct related social norms and conventions.

To further complicate matters, Proust refers to the "la ruse apparente des fleurs," ${ }^{28}$ wherein he comments on the manner in which nature governs reproduction in order to control and ensure continuation of the species. $\mathrm{He}$ extends the same concept to humans by comparing this idea to the manner in which the body responds to certain stresses. For example, fatigue follows too much pleasure. Flowers and insects explain the natural quality of the sexual encounters of the characters in Sodome et Gomorrhe, but at the same time they serve as a reminder of the need to avoid excess. However, the genesis of Proust's theory occurs in "La race maudite." The Marquis de Quercy, according to the observations of the narrator, always wears a boutonnière. When the narrator decides to attend the salon of the Guermantes, he decides to imitate the Marquis:

Je voulais me commander une boutonnière chez le fleuriste mais ma grand-mère trouvait qu'une rose de jardin serait plus 'naturelle.' Après avoir marché sur un massif en pente et en piquant mon habit aux épines des autres, je coupai la plus belle, et je sautai dans l'omnibus qui passait devant la porte...le parfum montait invisible...comme un secret d'amour. Et quand j'arrivai au moment d'entrer...j'étais pris dans le flot et ne pouvais plus rien faire, distrait d'ailleurs par la nécessité d'avoir à enlever mon pardessus, prendre un numéro, jeter ma rose qui s'était déchirée sous mon paletot et dont l'immense tige verte était tout de même trop 'naturelle.'29

Proust takes great care to valorize the natural quality of picking a rose from the garden rather than buying one from a florist. The flower is thus taken with some difficulty from the rosebush in a garden rather than acquired through a purchase or exchange of commodities. The scent of the rose is invisible and intoxicating, able to attract an insect, or vehicle, for pollination - a metaphor for sexual relations. Yet the flower possesses a fragile constitution, indicating the delicacy of desire in its myriad of expressions. When hidden, as the rose beneath the overcoat, desire cannot thrive. The enormous green stalk represents the phallic power that remains visible even after the petals of the flower are detached, which the narrator finds too natural, referring to the degree in which he is caught up in popular social conventions, all the more evident since he manages to keep company with a social class above his own. 
Returning to Sodome et Gomorrhe, Proust again invokes nature in order to bolster his hypothesis of the sexual encounter occurring outside the economics of nature and conventional moral order:

Comme tant de créatures du règne animal et du règne végétal, comme la plante qui produirait la vanille, mais qui, parce que, chez elle, l'organe mâle est séparé par une cloison de l'organe femelle, demeure stérile si les oiseaux-mouches ou certaines petites abeilles ne transportent le pollen des unes aux autres ou si l'homme ne les féconde artificiellement... (et ici le mot fécondation doit être pris au sens moral, puisque au sens physique l'union du mâle avec le mâle est stérile, mais il n'est pas indifférent qu'un individu puisse rencontrer le seul plaisir qu'il soit susceptible de goûter, et 'qu'ici-bas toute âme' puisse donner à quelqu'un 'sa musique, sa flamme ou son parfum'). ${ }^{30}$

This comparison between flowers and insects denotes the inherent complications of hooking up in both the plant and animal kingdoms. For example, the narrator gives the example of the orchid, a flower possessing both male and female sexual organs separated only by a partition. Yet the orchid depends upon birds or bees or artificial human interaction to ensure its pollination and reproduction. Parenthetically, almost as an aside or an afterthought, not meant to confuse the reader, Proust qualifies this type of fertilization from a moral perspective. In other words, in the physical sense the union of two males does not yield progeny. Yet these natural laws do not exclude the possibility of transgression driven by desire. Here the text suggests that pleasure can be experienced outside any established boundaries.

Conversely, we must now return to the beginning of the text to suture the dynamics of the pursuit of pleasure. The narrator therein launches a floral stratagem as a prelude to his observation of the Jupien/Charlus hook up:

Je savais que cette attente n'était pas plus passive que chez la fleur mâle, dont les étamines s'étaient spontanément tournées pour que l'insecte pût plus facilement le recevoir; de même la fleur femme qui était ici, si l'insecte venait, arquerait coquettement ses 'styles' et pour mieux être pénétrée par lui ferait imperceptiblement... la moitié du chemin. ${ }^{31}$

Both the male and female flowers actively respond to the advances of the pollinating insect. The male turns his stamens in order to receive, while the female extends herself in order to meet the insect. This cross-pollination provided by an external source ensures the survival of the species. This 
passage implies that the chance encounter of Charlus and Jupien serves to broaden and strengthen "la race maudite." The more this type of hook up takes place, the possibility of growth in numbers and the building of the community occurs.

In fact, the expansion of the community reaches its apotheosis in Le temps retrouvé, the final volume of $A$ la recherche du temps perdu. With the passage of time, the narrator and Jupien have matured, while Charlus appears as an elderly man whose sexual proclivities have reached new and greater heights. We find the narrator on his way home from an evening out with friends. However, he does not feel well and decides to find a hotel where he can rest a while and have a drink. What a surprise awaits his perpetual curiosity when he decides to check out the premises. He hears the sound of muffled cries in one of the rooms and decides to investigate. Placing his ear to the door, he hears the following exchange:

'Je vous en supplie, grâce, grâce, pitié, détachez-moi, ne me frappez pas si fort, disait une voix. Je vous baise les pieds, je m'humilie, je ne recommencerai pas. Ayez pitié. - Non, crapule, répondit une autre voix, et puisque tu gueules et que tu te traînes à genoux, on va t'attacher sur le lit, pas de pitié,' et j'entendis le bruit du claquement d'un martinet, probablement aiguisé de clous car il fut suivi de cris de douleur. ${ }^{32}$

This dialogue reveals two individuals in definite roles. One is being punished for some reason, and the other is administering discipline. While one voice pleads for mercy on his knees, the other refuses to desist and continues the torture while informing the suppliant that he is going to be tied to the bed because he is complaining and kneeling. The registers used indicate a relationship founded on power and submission. While the first voice uses the formal vous in sophisticated language, the second responds in a vulgar register and employs the familiar $t u$. Thus, the text already points to some type of derogation. The narrator remains within the discourse and comments on hearing the cracking of a whip, probably fortified with nails, followed by cries of pain. It is worth noting that during the late nineteenth and early twentieth centuries, the use of such instruments of discipline was common in convents and monasteries throughout Europe. Thought to quell the passions, the beatings were either administered by the individual or a confrere. Further along, Jupien indeed confirms his knowledge of this practice when he informs the narrator: "Ici, c'est le contraire des carmels, c'est grâce au vice que vit la vertu." ${ }^{33}$ Simply put, virtue exists due to vice and not the opposite. Such a commentary points to the reification of this practice, thus rendering it perverse rather than pious. 
Overtaken by inquisitiveness, the narrator finds a way to slip into the room unnoticed and beholds an impressive scene:

Enchaîné sur un lit comme Prométhée sur son rocher, recevant les coups d'un martinet en effet planté de clous qui lui infligeait Maurice, je vis, déjà tout en sang et couvert d'ecchymoses qui prouvaient que le supplice n'avait pas lieu pour la première fois, je vis devant moi M. de Charlus. ${ }^{34}$

Unlike his first aural experience of the Charlus/Jupien tryst, the narrator now observes Charlus during the act itself. Referring to Greek mythology, he compares Charlus to the hero Prometheus fettered to a rock and unable to escape, thus underscoring the aristocratic origins of the baron irrespective of the present circumstances which cause any social conventions to disintegrate. Already bloody, Charlus receives strikes from Maurice, a gigolo. The narrator notes that the baron is covered with bruises, indicating that this is not the first session he witnesses.

In the next section, the narrator sees Jupien enter the room to take control of the situation. After dismissing Maurice, Charlus expresses his doubts that the young man possesses the qualifications to function in the role of a master. Jupien reassures the baron in vain. Here the text reveals that the baron himself bought the hotel and hired Jupien to manage the operation behind the scenes and serving Charlus as a surrogate sex therapist. A sordid affair, we learn that the establishment is frequented by an array of clients, including a priest that the narrator initially mistakes for "une dame assez agée, en jupe noire," 35 showing a lack of respect for the clergy with the afterthought: "C'était cette chose si rare, et en France absolument exceptionnelle, qu'est un mauvais prêtre." 36 In other words, above all in France it would be an exception to find a bad priest. A perceived old woman in a black skirt seeking the services of a male brothel certainly does not represent virtue. Furthermore, when the priest forgets to pay, Jupien interjects: "Pour les frais de culte, monsieur l'abbé!" 37 The money taken covers the expenses of partaking of forbidden pleasures rather than the upkeep of a parish church. Finally, the narrator returns and adds: "Le vilain personnage s'excuse, donna sa pièce et disparut," now depicted as a depraved character who pays and then disappears. This passage constitutes an example of Proustian sarcasm at its best, squarely aimed at clerical hypocrisy, a prevalent public attitude at the time. After the baron leaves the premises, the narrator speaks at length with Jupien and expresses disgust of the operation: "C'est un vrai pandemonium." 39 Jupien responds with an invitation to the narrator to return and experience the ambiance, further destabilizing the social location. Dissolving the 
impassibility of any conventional boundaries through the Charlus/Jupien saga, Proust shows the fragility of sexuality and the power of desire.

From a more contemporary perspective, the French philosopher, writer, and gay activist Guy Hocquenghem articulates certain theoretical points which bolster Proust's positions and their relevance to current strands of queer scholarship. Published in 1972 following the events of May, 1968 and Stonewall, Hocquenghem's Le désir homosexuel offers a provocative analysis of desire. In the introduction to the most recent English edition, Michael Moon underscores the key to understanding this work:

[... the object of a given desire does not determine the 'nature' of that desire - that is, 'desire is desire,' to put it plainly, the apparent tautology intended to suggest that there is not some 'right desire,' heterosexual in nature, and some 'wrong' or 'misplaced' or 'perverted' one that is homosexual..$^{40}$

Clearly, pure desire defies any norms or markers related to morality, sexual orientation or gender: According to Hocquenghem, and following the theme treated by Proust, flowers and insects are not sexed. They are the machines of desire, thus creating a greater number of possibilities for plugging in.

In order to illustrate this point, Hocquenghem refers the Baron de Charlus and Jupien's complicated relationship:

De même tout se passe entre Charlus et Jupien sans nom. En vérité la machine de drague se moque bien des noms et des sexes. La dérive où toutes les rencontres deviennent possibles, c'est le moment où le désir produit sans culpabiliser. ${ }^{41}$

Hocquenghem relates that what passes between Charlus and Jupien has no name. This is particularly true in their first encounter. The cruising machine mocks taxonomy and sexual constructs. Moreover, the juncture where pleasure becomes possible refers to the moment in time when desire dominates without any feeling of guilt. This dynamic is transformed in the pages of Le Temps retrouvé, where pleasure equals pain and must be calculated, taking on the form of a simulacrum in the reproduction of a torture chamber.

In conclusion, "La race maudite," and selections from $A$ la recherche du temps perdu represent ground-breaking literary works that take on issues related to gender and sexuality that continue to challenge contemporary queer theory and scholarship. For example, the melancholic affect of Monsieur de Quercy, the seductive dance between Jupien and Charlus and the torture scene of the baron clearly reflect Judith Butler's ideas concerning gender performativity: 
$[\ldots]$ gender is performatively produced and compelled by the regulatory practices of gender coherence...gender proves to be performative - that is, constituting the identity it is purported to be. In this sense, gender is always a doing, though not by a subject who might be said to preexist the deed... There is no gender identity behind the expressions of gender; that identity is performatively constituted by the very "expressions" that are said to be its results. ${ }^{42}$

Decidedly, the constant marker that sutures Proust to Butler finds its valence in a particular performative context rather than any social construct. Whether through the abject affect of the Marquis de Quercy, the seduction dance of Charlus and Jupien, or the baron's self-designed torture chamber hidden in a hotel, Proust succeeds in dissolving the impassibility of any conventional boundaries. He shows the fragility of sexuality and the power of desire, while his sheer artistry blurs conventional linguistic gender markers. In sum, Proust deconstructs the heteronormative model. Indeed, following Hocquenghem's claim, desire will out.

\section{Notes}

1. Gilles Deleuze and Félix Guatarri, L'Anti-Oedipe (Paris: Minuit, 1972), 36.

2. Julia Kristeva, Pouvoirs de l'horreur (Paris: Editions du Seuil, 1980), 9.

3. Judith Butler, Bodies that Matter: On the Discursive Limits of "Sex" (New York: Routledge, 1993), 3.

4. Marcel Proust, "La race maudite" in Contre Sainte-Beuve (Paris: Editions Gallimard, 1954), 248-49.

5. Ibid, 249.

6. Ibid, 252.

7. Ibid, 254-55.

8. Ibid, 257-58.

9. Ibid, 260.

10. Ibid, 260.

11. Marcel Proust, Sodome et Gomorrhe (Paris: Éditions de la Pléiade, 1988), 3.

12. Ibid, 3.

13. Ibid, 6 .

14. Ibid, 9 .

15. Ibid, 11 . 
16. Michel Foucault, Histoire de la sexualité I (Paris: Editions Gallimard, 1980), 72-73.

17. William C. Carter, Marcel Proust, a Life (New Haven: Yale University Press, 2000), 743.

18. Ibid, 743.

19. Proust, Op. Cit., 6.

20. Ibid, 7

21. Ibid, 11

22. Walter Benjamin, "The Image of Proust," in Illuminations (New York: Shocken Books, 1985), 206-207.

23. Ibid, 208.

24. Ibid, 18.

25. Foucault, Op. Cit., 59.

26. Proust, Op. Cit., 33.

27. Ibid, 22.

28. Ibid, 5.

29. Proust, "La race des tantes," 243-44.

30. Proust, Sodome et Gomorrhe, 28.

31. Ibid, 4-5.

32. Marcel Proust, Le temps retrouvé (Paris: Éditions de la Pléiade, 1989), 394.

33. Ibid, 409.

34. Ibid, 394.

35. Ibid, 407.

36. Ibid, 407-408.

37. Ibid, 408.

38. Ibid, 408.

39. Ibid, 411.

40. Guy Hocquenghem, Homosexual Desire (Durham, North Carolina: Duke University Press, 1996), 17.

41. Guy Hocquenghem, Le désir homosexuel (Paris: Fayard, 2000), 150.

42. Judith Butler, "Subjects of Sex/Gender/Desire," in Gender Trouble (New York: Routledge, 1999), 25. 



\section{Patterns of Feminine Discourse in Samuel Beckett's Pas Moi}

Dr. Marzia CAPORALE

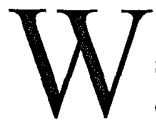

ith the exception of Oh les beaux jours, Samuel Beckett's theater from the 1960's on drastically moves towards a process of reduction of body and language. Pas moi, in this sense, fits the profile of Beckett's later works where minimalism is an essential part of both text and performance. On stage, there is no longer a character as such but only a portion of one. In this play, the protagonist is Bouche who, as her self-explanatory name states, is simply a mouth: the body of the woman who utters the eighteen-minute long tirade is completely hidden in the dark, absent at all effects and replaced only by her language. In front of her is a mysterious figure, Auditeur, who lacks both the physical and the linguistic consistency of a real character: he never speaks, at least audibly, and his body, as Beckett states in the stage directions, is wrapped in an ample robe, a djellaba which hides him and makes him virtually non-existent to the audience's eyes. Auditeur passively listens to the frantic speech of his counterpart, his only purposeful action being a hand gesture whose intent is to make Bouche use the first person pronoun "je" in place of "elle." 1

Critics have traditionally read Pas moi as an example of Beckett's distrust towards language and communication. Ann Wilson calls Bouche a "castrated voice" while Jude Meche defines her speech as "empty and obsessive." ${ }^{2}$ The critical doxa has almost unanimously perceived Bouche's 
linguistic paralysis and her inability to produce coherent speech as semiotic failure. From this perspective, the fragmentation of body and language of the mouth on stage leads to the character's inability to create a viable identity: broken words plus broken female body equals broken woman. Without denying Bouche's fragmented condition, I will argue that such fragments of body and language do not lead to empty or broken discursive practices and that they do not prevent the construction of a functioning feminine identity. In particular, my discussion of the play illustrates how the mouth in Pas moi achieves meaningful communication despite the character's elliptic presence on stage. Bouche's disorderly verbal stream addresses (and partly solves) fundamental questions linking female gender and subjectivity. She is a woman born into a cultural and linguistic pattern of masculine superiority: yet, she fights to gain access to a speech that may define her disjointed feminine self. In order to produce viable verbal communication, Bouche rejects a linguistic model made of chronologically linear events and replaces it with a communicative system built on broken logical connections, repetitions, and returns to better fit her fluid identity.

The play traces Bouche's painful steps towards linguistic selfrealization. Although late in life (she is soon to be seventy years old), she attempts to establish subjectivity through a mostly verbal practice, as her body alone cannot tell the story. Bouche's quest for an undivided identity takes the shape of a monologue, interrupted four times by Auditeur's gestural intervention ("quatre gestes brefs" 81). His silent reminder to Bouche to use the first person subject pronoun "je" while talking about herself is met regularly with a strong refusal on her part: "quoi? qui? Non... ! elle!" (82). Despite her emphatic rejection of "je," it is clear that, through her speech, Bouche is reliving her own personal experiences of isolation and estrangement. During her "confession," she admits that the words she utters are separate from her, that she has "aucune idée de ce qu'elle raconte," (87) thus displaying a clear disjunction of her "self" from the discursive practices she engages in. Bouche struggles with the impossibility of saying "I," as she can only be defined by something other than herself: either "elle" or the "not I" of the title. As Ann Wilson observes, "Mouth steadfastly refuses to inscribe herself as the fully present speaking subject but instead insists that the story is that of "she" (193). Indeed, this character has no choice but to speak in the third person. The use of the first person pronoun would not be adequate in representing her. If she were whole, she might be able to identify with such a pronoun: however, she is only a piece of a female body, a mouth who wants to speak but who must first acquire the linguistic tools that will allow her to do so. 
Born a woman and therefore "cursed" by her female condition, Bouche initially reproduces in her speech the schemes and parameters of a patriarchal discourse to which she only apparently subscribes. In reliving her most significant life events, Bouche recalls being the object (and the victim) of a strict and unchallengeable order which denied her any possibility of becoming a "speaker" for a long period of time. Her being destined to silence is implicit in the account of her birth, in which womanhood and nothingness are viewed as one and the same. As a woman, Bouche is destined to accomplish nothing of any value, as she admits: "monde ... mise au monde ... ce monde ... petit bout de rien ... avant l'heure ... loin de - quoi? ... femelle? ... oui ... petit bout de femelle" (82). ${ }^{3}$ The expressions "petit bout de rien" and "petit bout de femelle" are interchangeable in this context, as are the two terms rien/femelle. Such a view, however, is not truly her own. By calling herself a "nothingness" or a "tiny little thing" (216) as she does in the English version, Bouche is simply repeating a pattern of masculine superiority that is culturally acquired: she will never truly have a voice as a subject because she was born an object and any attempt to overturn the male/female hierarchical order will result in failure. In her opening statement, Bouche presents herself as apparently in line with the rules of patriarchy that consider females as less valuable than males. The birth of a girl is a less fortunate event than the birth of a boy: according to this cultural paradigm, Bouche is worthless and shall remain voiceless for the rest of her life.

The text seems to support this theory by presenting Bouche's birth as a series of negative events. This child arrived before her time and was the product of a mere sexual encounter between two people who abandoned her and who had no parental role during her infancy and beyond: "père mère fantômes ... pas trace... lui filé ... ni vu ni connu ... pas plus tôt boutonnée la braguette ... non, point d'amour" (82). For many Beckettian characters, from Winnie in Oh les beaux jours to Hamm in Fin de partie, the birth of a new life, is not a blissful event but rather an act of cruelty which will lead to a life of misery. ${ }^{4}$ Therefore, Bouche's birth is characterized, both grammatically and semantically, by negation and absence. No trace of the father, no love. Her beginnings can only be defined by what was not, just as in her present condition, her story can only be told by what she is not ("pas moi").

Through her speech, Bouche displays a sense of disintegration of the self. The insistence on "she," "not I" (the original English title of the play) reproduces, by a fairly obvious pun, the physical reality suggested by the title. The voice who speaks is "mouth," "not eye:" she is a piece 
separated from the rest of the body and forced to exist independently from it. Indeed, the reiterate use of "elle" is indicative of Bouche's sense of alienation from herself and from the world. The character is haunted by a sense of not belonging, of having lost her direction, as shown by memories of her drifting silently through a supermarket, a courthouse, and a home. In recounting the wanderings of her silent days, Bouche recalls that words came to her before she reached the prairie, the site of a longawaited linguistic rebirth. The sound of a bumblebee in this open space interrupts the quiet of her surroundings and marks her transition towards speech:

Oui ... silence de tombe à part le bourdon ... soi-disant ... quand soudain elle sent venir des - ...quoi? ...qui? ... non! elle! ... (pause et deuxième geste) ... sent venir des ... des mots ...imaginez ! ... des mots ! ... une voix que d'abord ... elle ne reconnait pas ... depuis le temps ... puis finalement doit avouer ... la sienne ... nulle autre que la sienne (86-87).

When the linguistic epiphany finally occurs, Bouche struggles to find her voice and fails to recognize the words she utters as her own. When attempting to invent patterns of a new, viable feminine discourse, she is initially confronted with the inability to engage in verbal practices that can adequately represent her. Yet, her voice gradually builds upon itself, one word after another, leading to the creation of a new story that Bouche will eventually tell in her own words.

This new story and the character's first encounter with language happen in an open and neutral space, the aforementioned field which returns periodically in her monologue. The closed spaces she had named, from the home to the supermarket to the courthouse, find her paralyzed and unable to utter a single word. The home in particular, as Kathleen O'Gorman remarks, "is the traditional site of the female subjugation to the law of the father who relegates her to the status of property" (81). By finding herself in the field, Bouche is free of spatial and socio-cultural boundaries: there, she can transgress the rules of a system that would want her conforming to the socially imposed role of wife, mother, and homemaker. The price to pay for non-conformity is exemplified in the reference to the courthouse and in Bouche's appearance in front of the judge. When called upon to defend herself for (presumably) having transgressed an acceptable unspoken code of feminine behavior, she displays a passive and victim-like attitude:

ce jour au tribunal ... qu'avait-elle à dire? Coupable ou non coupable? ... debout l'accusée ... répondez, l'accusée ... plantée là, ... les yeux dans le vide, bouche bée comme d'habitude ... attendant qu'on l'emmène ... (92). 
Although the reasons for her being brought to court are not clear, her crime is seemingly one of insubordination to patriarchal laws. Confronted with the power of male authority in a place (the courthouse) where women feel notoriously intimidated, Bouche has no choice but to remain silent.

During her voiceless years and through her peregrination from one place to the next, Bouche strives to find a center of balance for herself: technically, being just a fragment of a woman's body, she does not entirely belong to a feminine episteme and therefore cannot adhere to a specifically feminine behavioral paradigm. Furthermore, her first attempts at speech occur within a male-dominated verbal system which represses her feminine voice. As O'Gorman explains, "the first intelligible words Mouth speaks indicate the female displacement within the phallic order" (78). For this very reason, "she cannot assume a subject position within this order, cannot challenge the dominant discourse within which she has been inscribed" (79). Her linguistic displacement within the phallic order and the necessity to replace it with a new pattern of feminine discourse is emphasized by the reference to the lavatory where Bouche goes to "empty" herself, both physically and linguistically. This passage, which immediately follows the aforementioned mock trial, represents another instance of verbal epiphany: language gushes out of the character's body with a violence which is cathartic and liberating at the same time: "envie de raconter ... alors sentir comme une folle se jeter sur le premier venu ... la cuvette la plus proche ... s'y vider... . ce flot continu" (93). The stream mentioned in this passage is intentionally undefined and can equally be read as an outpour of words, vomit or menstrual flow (ce flot continu). The latter appears particularly relevant in this context since Bouche, who functions primarily as a mouth, can also be seen as representing a woman's reproductive organ. This component is more powerful in the play's television adaptation, which allows for close-ups of the moving lips, than in the theatrical version where the audience is necessarily positioned at a certain distance from the stage. ${ }^{5}$ Nonetheless, Bouche's metonymical function as the female sexual organ remains a powerfully suggestive image: in this sense, the continuous flow would indicate a woman's non-fertile time of the month. The menstrual cycle is a time during which the uterus restores its fecundity and later prepares for possible procreation. Similarly, after years of linguistic sterility, Bouche renews herself and experiences a period of fertility generating life through speech.

The character's newly found words are essential in filling the blank canvas of her feminine identity. Her story underscores her refusal to succumb to a linguistic absence. The often hysterical account of the events 
that develop between the time of her birth and her reaching the age of seventy does not follow a linear order and is deliberately built on a series of analeptic and proleptic segments. The account of Bouche's birth at the opening of her monologue is immediately followed by considerations about her old age and by the recollection of the yet unexplained linguistic awakening in the prairie. This last pivotal event is curiously placed in an anticlimactic position, at the opening of the play, and is built on the presence of opposing images of darkness and light, to signify the split identity of the speaker herself: "soudain ... peu à peu... tout s'éteint, toute cette lumière matinale ... début avril ... et la voilà dans le - ... quoi? qui? non! ... elle! ... (pause et premier geste) ... la voilà dans le noir" (82). The choice of April as the time for this episode is indicative of Bouche's refusal of a paradigmatic use of language. Conventionally associated with spring and images of rebirth and fertility, here April is connected with darkness. Visually and syntactically, the noun is placed in between images of gloominess (tout s'éteint/noir), thus overturning its archetypal signification which sees it as the month of light and joyful beginnings.

Bouche's speech turns the month of April in particular and spring in general from the season of life to the season of death. ${ }^{6}$ The word undergoes a process of transformation, an interrogation of reality similar to that of abstract art, according to Pascale Casanova who, Beckett l'abstracteur, states:

pour rompre avec la signification et le référent, inhérents au langage, Beckett ne travaille pas sur la matérialité sonore du mot: il est conduit à mettre en cause, les unes après les autres, toutes les conditions de possibilité ordinaires de la mémoire, l'imagination, le sujet, la narration les personnages, la psychologie, l'espace, le temps (9)

Words are familiar and yet estranged: logical connections are undermined, and the denotative value of language is questioned. More examples of this mechanism, which leads to a general displacement of meaning, can be found in Bouche's multiple references to God throughout the play. The story of how the character came to speak is permeated with Christian overtones. When reconstructing the birth of her language, she paraphrases the Bible to fit her own story of aphasia:

car première chose l'idée... oh bien après...brusque illumination ... dressée qu'elle avait été à croire ... avec les autres abandonnés ... en un Dieux ... (bref rire) ... miséricordieux (bon rire) ... première chose donc l'idée ... oh bien après ... brusque illumination ... que la voila punie ... en voie d'être punie (83) 
The biblical "in the beginning was the word" is echoed in "première chose l'idée." The God who created the world and the word is a falsely merciful father who punishes her for having defied his power. The referential meaning of miséricordieux is immediately annulled by Bouche's sarcastic laugh before and after she pronounces the word. The God she portrays is a vindictive figure, a male deity who does not show mercy, not unlike the previously mentioned judge in the court house: both accuse Bouche of crimes and sins she never committed and are unwilling to listen to her defense.

The crime and the sin remain equally unspecified: nonetheless, in feminist terms, it can be argued that, in allowing herself to create new words, Bouche has taken the role of God upon herself. By producing her own language, she has challenged that same law of the father that wanted her silent and is punished for having gone beyond the limits of what is permissible for a woman. As Susan Gubar observes, "Christianity, as feminist theologians have shown us, is based on the power of God the father who creates the natural world of generation out of nothing" (293). Creation is a masculine privilege. Women cannot create, they do not have the power to produce anything new: they can be art objects but not artists or creators themselves. During her aphasic years, Bouche was denied any possibility of creation. Her body's desires remained unvoiced and her sexuality was annulled, as she recounts: "alors qu'elle était presumée ... toute évidence ... éprouver du plaisir, elle n'en éprouvait aucun" (83). The episteme which Bouche reproduces in her discursive practices stems from the patriarchal notion that female desire is to be suppressed and denied. Hence, for the character, coming to language signifies regaining her once suppressed sexual awareness: her new identity will be constructed regardless of the laws of a masculine discourse that would want her body and language to remain silent. Indeed, Bouche's speech, although shaky and uncertain at first, eventually explodes into an endless stream of words and into a linguistic jouissance. In her attempts to make new (fertile) sense out her language and her body, she does what Cixous describes in "Le Rire de la Méduse:"

Si la femme a toujours fonctionné "dans" le discours de l'homme, signifiant toujours renvoyé à l'adverse, signifiant qui en annihile l'énergie spécifique ... ., il est temps qu'elle disloque ce "dans," qu'elle l'explose, le retourne, le saisisse, qu'elle le fasse sien, le comprenant, le prenant dans sa bouche à elle. Que de ses dents à elle elle lui morde la langue, qu'elle s'invente une langue pour lui rentrer dedans (49). 
Piece by piece, Bouche creates a feminine speech that allows her to become the sole protagonist of the play in both body and language: her audience (Auditeur), who is male, never utters a word. She is the sole creator of the speaking act and is the only character who can keep absence from happening. The "sense" of her verbal production, which lacks logic and order, is precisely in the attempt to replace absence with a tangible presence: her words fill the theatrical space while at the same time building the framework of her new identity.

The last few lines in Pas moi reinstate several leitmotifs of the play and confirm the choice of a speech pattern that refuses to adhere to the rules of a logocentric and linear discourse: "Dieu est amour ... bonté intarissable ... chaque matin nouvelle ... rendue à la prairie .... matin d'avril ... visage dans l'herbe ... seule au monde ... avec les alouettes ... reprendre la ... repartir de -" (94-5). Circularly, Bouche goes back to the April morning of her linguistic birth, to her loneliness and isolation, and to the God who had punished her. In particular, God appears in her final words but only as a cliché and an empty signifier ("Dieu est amour"). Again, such statement needs to be read through a semantic reversal. In Bouche's value system, God is not love. He, like the judge in the courthouse, or the father who abandoned her, has shown her no love and has punished her unfairly. A few moments earlier in her speech, Bouche had acknowledged the uselessness of her prayer which was "pas entendue ... trop faible" (94). ${ }^{7}$ The act of praying in this context becomes a futile ritual. As Knowlson and Pilling rightly argue, "like Winnie in Happy Days, Mouth seeks comfort from familiar phrases which can, however, provide her with no sense of permanent release" (202). When she attempts to revert back to that same language of patriarchy which her speech is undermining, she discovers that those words and phrases are estranged from her. For this reason, she abandons them in favor of her own fragmented speech which better describes her feminine identity in the making.

The quest of a woman (or part of one) who seeks to define herself as a speaking subject leads to questions of gender and identity in the play. Contrarily to what Beckett repeatedly stated about the irrelevance the sex of his characters, Pas moi confirms that gender issues in Beckett's work cannot be ignored. ${ }^{8}$ Bouche and Auditeur find their origin as characters in two specific figures that the author had observed in two distinct occasions. Deirdre Bair recalls that the idea of a mouth separated from the rest of the body derives from "The Beheading of St John," a painting Beckett had seen in Malta shortly before the play was written. Similarly, Auditeur, all dressed in black, was inspired by a scene he had witnessed in Morocco 
of an Arab woman wrapped in a djellaba who was anxiously waiting for her child to arrive on the school bus. He was struck by her "attitude of intense waiting" and by her gestures of flapping "her arms aimlessly against her sides" (622). These two powerful images were reworked to fit the characters' roles and relations in the play. Notably, the gender of the two figures at the origin of Bouche and Auditeur was reversed. The head of St John became the mouth of a woman and the female figure in the djellaba became a male listener.

Bouche's speech is unmistakably and deeply feminine and a gender role reversal in the play would simply not be possible. Additionally, the character, as Beckett himself stated, has its direct origin in the idiosyncrasies of the "Irish bag lady." As he explains, "there were so many of those old crones, stumbling down the lanes, in the ditches, besides the hedgerows. Ireland is full of them. And I heard her saying what I wrote in Not I. I actually heard it" (Knowlson, Damned to Fame 522). Bouche is a part of a woman whose painful experiences of subjugation to patriarchal laws, denial of speech, and suppression of sexuality are unmistakably feminine. In particular, Bouche's life-long verbal struggle to rise beyond a paralyzing linguistic semiotic discourse inscribe the character inside an all-feminine episteme. Despite her interrupted language, she is able to construct a feminine moi outside and beyond the rules of an inadequate phallic order. Bouche's coming to speech and the creation of a viable "self" can be summarized again by Hélène Cixous' experience of coming to writing. In addressing the challenges female speakers face when attempting to establish a feminine identity through speech, she asks herself: "je suis ... qui serait parler comme Dieu? Pas je .... . Ce que j'étais, était un tourbillon de tensions, une série d'incendies, dix mille scènes de violence" (26). Cixous labels "je suis" as the language of God the father, as a model of verbal communication which does not belong to woman and therefore cannot define her. Bouche experiences the same inability to belong to her body, to language, and consequently, to the outside world. Feeling estranged from the conventional first person subject pronoun, she can only attempt to verbally define herself through pronoun other than "je." For this reason, she will never be able to let go of "elle:" the pronoun sets her apart as something other than " $I$ " while at the same time identifying her as a feminine subject.

In discussing issues of representation of the body through language, Helena Michie argues that "since our knowledge of the self is constituted in and by discourse, we can only construct for ourselves a body in pieces, a corps morcelé" (149). Bouche's body is indeed morcelé, as is her speech. 
The mouth is normally the vehicle of expression of the thoughts produced by the brain. In the play, however, there is no head, only a mouth with its lips, teeth and tongue. In this sense, language and body follow the same pattern of disintegration: a body in pieces can only express itself through pieces of language.

Nonetheless, despite her linguistic fragmentation, Bouche successfully creates her own "rules" of play. Her speech destroys the logos and all its foundations while working to rebuild a functioning feminine linguistic system. Inevitably, during this process, Bouche's language sounds like a broken record and falls into a series of repetitions and ellipses. Her words reject conventional syntactic and semantic channels and replace them with minimal grammatical structures made of verbs in the infinitive, nouns without verbs, and participes présents: "le cerveau ... plein délire là aussi ... à vouloir y trouver un sens ... ou y mettre fin ... ou dans le passé ... trifouillant dans le passé ... petites scénettes éclair ... balades surtout, toute sa vie à se balader " $(89-90)$.

Such seemingly chaotic linguistic choices are not the result of a semiotic paralysis on the part of the speaking subject: on the contrary, they are indicative once more of Bouche's refusal to inscribe her language production within a logocentric system of speech. Similarly, her final refusal to relinquish the use of "elle" does not imply a defeat on her part. At the end of her monologue, Bouche remains unable to abandon the use of the third person pronoun and returns to "elle" a few moments before the play closes. Through such refusal, Bouche states the impossibility to write her history within the phallic order. Producing speech outside male-centered discursive practices is not a fruitless effort and the play does not portray an irreversible linguistic crisis. Pas moi shares in the breakdown of referentiality that characterizes Beckett's "mature" writing while at the same time proving the impossibility of achieving a completely non-referential type of theatrical representation. Bouche may miss all the elements that make up a conventional character in theater (body, movement, psychology) but she ultimately proves with her speech that she can break the silence she was originally destined for.

The powerful image of the dismembered body of a woman who tries to reconstruct her "self" by letting her mouth recount her coming to language, leads to an interrogation about the female body and its ability (or inability) to produce meaning through gesture and verbal discourse. A whole identity may never be constructed, as the body's wholeness is irremediably lost. Nonetheless, words remain at the core of the theatrical performance and justify Bouche's existence as a character. Although she 
is not able reach the full status of "I," she manages to recreate the story of how she replaced absence with presence, despite her fragmented speech and her (almost) non existent body. By giving voice to a part of her body which had been quiet all her life, Bouche proves that she possesses the ability to create meaning after all. While the play confirms the crisis of the logos (on and off stage), it does not allow for a hopeless view of the communicative and representational processes. Once language comes to Bouche, she fights to make sense of it, regardless of broken grammatical rules or logical connections. The presence of a "piece" of this old woman suffices to create the identity of a strong female character whose words tell the powerful tale of how she became a mouth no longer afraid to speak her own language.

\section{Notes}

1. I refer to Auditeur in the masculine since Beckett uses this term (and not Auditrice) in the French text.

2. See Ann Wilson, "Her Lips Moving: the Castrated Voice of Not I" and Jude Meche, "Beckett's Not I: Empty Speech and Obsession in Mouth's Dialogue."

3. The French version is more explicit in identifying "fille" with "rien." The English text, Not $I$, reads: “... out ... into this world ... tiny little thing ... before its time ... in a godfor- what? ... girl? ... yes, tiny little girl ... into this ... out into this ...before her time ... godforsaken hole called ... called ... no matter" (216).

4. In Ohles beaux jours, Winnie sees the sterility of the land around her as a blessing: "Quelle bénédiction que rien ne pousse, imagine-toi si toute cette saloperie se remettait à pousser" (41). In Fin de partie, Hamm repeatedly curses his father for having brought him into this world by calling him a "maudit progéniteur" (23), a "maudit fornicateur" (24) and by later asking the rhetorical question "Salopard! Pourquoi m'as tu-fait?" (69).

5. Beckett intended to suggest the connection to the female genitalia in the stage version of the play but did not want its effect to be overpowering. For this reason, the BBC film version of Pas moi was shot in black and white, color adding too much of an open sexual tone to the play. As Knowlson and Pilling remark, "in the television version Beckett realized that Mouth had the appearance of a large gaping vagina" (200). Similarly, Thomas Simone observes that in the BBC version "the visual effect of the play is intensely emotional and erotic" ("Beckett's Other Trilogy" 59). 
6. In Fin de partie Beckett had questioned the validity of the association between April and happiness with an exchange between Nell and Nagg:

Nell: Nous nous sommes promenés sur le lac de Côme. Une après-midi d'avril.

Nagg: On s'était fiancés la veille.

Nagg: Fiancés! (36)

The cliché image of the month of April, normally associated with spring, youth, and life appears paradoxical in a context where only old age and death dominate.

7. To be compared with Winnie's inaudible prayer in Oh les beaux jours. Her "Jesus-Christ Amen" and "siècles des siècles amen" $(12,13)$ are empty formulas which have no context since the prayer itself cannot be heard and is, therefore, in theatrical terms, non-existent. The act of praying becomes progressively more meaningless and Winnie at the end of act one can no longer put it into practice after telling herself "prie ta vieille prière, Winnie" (57).

8. In Malone meurt, Beckett states: "Il y a si peu de différence entre un homme et une femme, je veux dire entre les miens" (10).

\section{Works Cited}

Bair, Deirdre. Samuel Beckett. A Biography. NY: Touchstone, 1978. Beckett, Samuel. Oh les beaux jours suivi de Pas moi. Paris: Minuit, 1963-74.

. Malone Meurt. Paris: Minuit, 1951.

. Not I. Collected Shorter Plays of Samuel Beckett. London: Faber and Faber, 1984.

Casanova, Pascale. Beckett l'abstracteur: anatomie d'une révolution littéraire. Paris: Seuil, 1997.

Cixous, Hélène. Entre l'ecriture. Paris: Des femmes, 1986.

Gubar, Susan. "The Blank Page and Female Creativity." In The New

Feminist Criticism. Ed. Elaine Showalter. New York: Pantheon, 1985. Knowlson, James. Damned to Fame: the Life of Samuel Beckett. NY:

Touchstone, 1996.

Knowlson, James and John Pilling. Frescoes of the Skull: The Later Prose and Drama of Samuel Beckett. London: Calder, 1979.

Meche, Jude. "Beckett's Not I: Empty Speech and Obsession in Mouth's

Dialogue." Studies in the Humanities 25. 1-2 (1998) 101-11. 
Michie, Helena. The Flesh Made Word: Female Figures and Women's Bodies. New York: Oxford UP, 1987.

O'Gorman, Kathleen. "'But This Awful Thought:'Aspects of the Female in Beckett's Not I." Journal of Beckett Studies 1 (1992) 77-94.

Oppenheim, Lois. "Female Subjectivity in Not I and Rockaby." In Women in Beckett: Performance and Critical Perspectives. Ed. Linda BenZvi. Urbana: U of Illinois P, 1990, 217-227.

Simone, Thomas. "Beckett's Other Trilogy: Not I, Footfalls and Rockaby" Make Sense who May: Essays on Samuel Beckett's Later Works. Eds. Robin J. Davis and Lance Butler. Gerrards Cross: Colyn Smythe, 1988.

Wilson, Ann. "Her Lips Moving: the Castrated Voice of Not I." In Women in Beckett: Performance and Critical Perspectives. Ed. Linda BenZvi. Urbana: U of Illinois P, 1990, 190-200. 
